\title{
Valorization of Biomass Residues by Biosorption of Microelements in a Closed-Loop Cycle
}

\author{
Bartosz Ligas $^{1}$ D $\cdot$ Jolanta Warchoł $^{1} \cdot$ Dawid Skrzypczak $^{1} \cdot$ Anna Witek-Krowiak $^{1} \cdot$ Katarzyna Chojnacka $^{1}$
}

Received: 5 July 2021 / Accepted: 12 November 2021 / Published online: 27 November 2021

(c) The Author(s) 2021

\begin{abstract}
The concept of the research data presented assumes the valorization of goldenrod residues from supercritical $\mathrm{CO}_{2}$ extraction following the circular economy principles. The biomass was enriched with microelements $(\mathrm{Cr}, \mathrm{Zn}, \mathrm{Cu})$ by biosorption from single and multielemental solutions in batch and packed bed reactors. Modeling of biosorption equilibrium supported by instrumental analysis (SEM and FTIR) of material properties was employed to explain the metal ions binding mechanism. The preferential biosorption of $\mathrm{Cr}$ (III) over the divalent ions, allows the possibility of valorization of goldenrod residue in a garden-scale biosorption tank acting as a fixed-bed reactor working in an open circulation run and fed with microelements diluted in rainwater. The use of fertigation solution in optimal doses of micronutrients did not show any phytotoxic effect. Using the post-sorptive solution as a source of micronutrients for plants showed significant effects on growth parameters (increased chlorophyll content by 54\%) compared to groups fertilized with commercial formulation (13\% higher sprout mass). Additionally, fertigation with the post-sorption solution leads to the biofortification of cucumber sprouts. The recycling process results in two products: enriched biomass as a potential feed additive (with $\mathrm{Cr}(\mathrm{III}), \mathrm{Cu}(\mathrm{II})$, and $\mathrm{Zn}$ (II)) and a post-sorption solution (with $\mathrm{Zn}(\mathrm{II})$ and $\mathrm{Cu}$ (II) only) used in the fertigation of plants.
\end{abstract}

\section{Graphical Abstract}

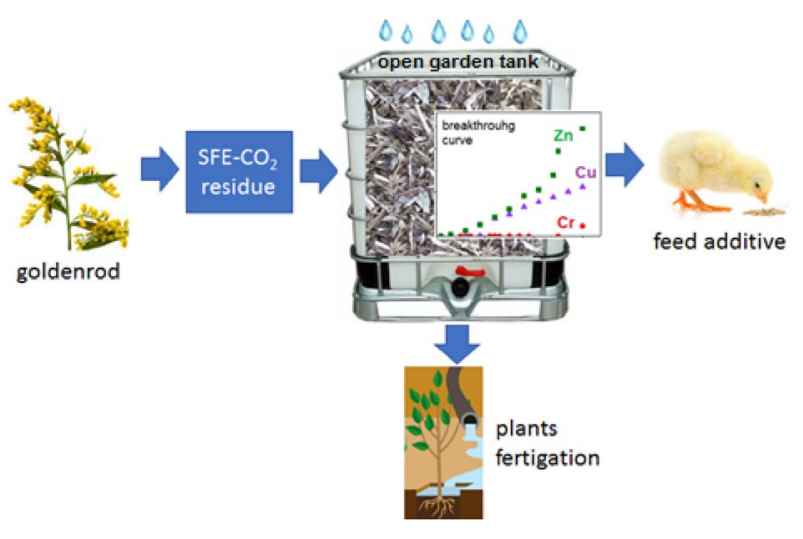

Keywords Biomass valorization $\cdot$ Micronutrients $\cdot$ Feed additives $\cdot$ Fertigation $\cdot$ Waste management

Bartosz Ligas

bartosz.ligas@pwr.edu.pl

1 Department of Advanced Material Technologies, Faculty of Chemistry, Wrocław University of Science and Technology, Smoluchowskiego 25, 50-372 Wrocław, Poland

\section{Statement of Novelty}

This work is experimental research that can contribute to achieving sustainability, with respect to its energy use and carbon footprint, by coordinating supercritical $\mathrm{CO}_{2}$ extraction $\left(\mathrm{SFE}-\mathrm{CO}_{2}\right)$ unit owners and small scale farmers. The problem with using SFE- $\mathrm{CO}_{2}$ solid extraction is 
the accumulation of post-processed biomass. Because of its low calorific value, it is not suitable for energy production, so it must be disposed of. Due to the long decomposition time, this operation generates additional costs. To solve that problem we highlighted the idea of enriching the biomass with microelements, by rainwater and salt of trace elements usage. It is a significant advance over past works due to applying the post-treatment solution as a source of micronutrients for plant cultivation.

\section{Introduction}

In recent years, the recovery of resources has become one of the main ideas of the sustainable development concept, circular economy, and zero-waste production approach. Major drivers for changing worldwide perception of this problem are projected scarcity of natural resources due to climate change processes, future depletion of non-renewable resources or limitations of their availability, and many socioeconomic factors [1].

The European Commission's goal is a reduction by $30 \%$ of non-renewable resources used in fertilizer production. This can only be accomplished by waste valorization and the circular economy (CE) approach. A circular economy is a system that is based on the recovery of materials. The European Commission introduced this concept as a response to environmental and social problems [1].

Valorization of plant residue of pharmaceutical, cosmetic, and food origin is a new opportunity for a circular economy enabling biomass used as a food supplement for livestock production [2,3]. A good example comes from a soybean meal commonly used in livestock farming as a source of assimilable protein. This biomass enriched with $\mathrm{Cr}, \mathrm{Zn}$, $\mathrm{Fe}$ and $\mathrm{Cu}$ ions, added to the laying hens feed, positively affected egg size and increased the transfer of microelements to the yolk fraction [3, 4]. Another waste-turn-intofeed example is cultivated algae Enteromorpha prolifera and Cladophora sp., used as a hens microelement source. Its application enhanced the size and thickness of eggshells $[5,6]$. The biomass of algae enriched with $\mathrm{Cu}$ was used in swine breeding, its bioavailability [7]. Feed additives obtained through sorption of $\mathrm{Cr}, \mathrm{Zn}, \mathrm{Cu}$ and $\mathrm{Mn}$ ions on alfalfa biomass were used as potential ingredients in feed for hen husbandry [2].

To be used as a feed additive, biomass should meet the appropriate moisture and ash content $(2.2 \%)$, contain no more than 100 times the standard content of a given substance in a complete meal and be free of faeces, urine, gut contents, treated leather, wood treated with preservatives, package or municipal solid waste and toxic elements [8]. All these requirements are met by plant residues from a supercritical fluid extraction (SFE) process. Thanks to the low process cost and the lack of necessity for solvents removal, SFE technique fits the trend of green chemistry and political directives limiting the negative impact of industry on the environment [9]. Re-use of the entire remaining post-extraction biomass is the last element required for a waste-free process status acquisition. In this context, valorization of the SFE residues and their usage as a feed additive is in line with the circular economy concept: the use of by-products from one production process as secondary raw material in another.

The by-products of SFE are low-density fibrous materials that are low in nitrogen, soluble carbohydrates, minerals and vitamins, and with varying amounts of lignin and cellulose. The three-dimensional polymer structure of lignocellulose creates the surface area where functional groups suitable for metal binding are localized [10-12] (Volesky and Holan, 1995). For example, methoxyl, hydroxylaliphatic, phenolic, hydroxyl, and carboxyl groups were identified in the polysaccharide cell wall of aster group plants. Phenolic groups are present on the lignocellulose matrix of black locust, while amide and amine groups in the case of ginger [13]. Thus, the presence of lignin and cellulose and types and amounts of functional groups involved are factors enabling biomass enrichment with microelements [14]. Moreover, organoleptic properties of biomass such as taste and smell or the content of medical substances (e.g., flavonoids, saponins) are also under great importance for livestock farming.

European goldenrod (Solidago virgaurea) is a perennial flower from the aster family, occurring originally in Europe, central Asia and North America. Beekeepers mainly cultivate this plant because of the positive effect on the taste, colour and health properties of honey [15]. Also, the pharmaceutical industry takes advantage of Solidago virgaurea extracts, which contain from 0.5 to $1.5 \%$ of flavonoids and other compounds from anthocyanin groups such as saponins and caffeic acid esters. The inclusion of $7.85 \%$ hemicellulose, $52.78 \%$ lignin and cellulose (with at least $28 \%$ of lignin content) [16], acts as a physical barrier impeding the microbial breakdown of goldenrod residue. Such composition extends its fermentation and creates a problem with its storage. So far, the SFE residue of goldenrod is not recycled or used in an alternative way.

This work aims to valorize locally available large quantities of the European goldenrod residues from SFE process and their valorization as a feed supplement enriched with microelements. Chromium (Cr), zinc ( $\mathrm{Zn})$ and copper $(\mathrm{Cu})$ were selected as model trace elements in this study due to their dual function in maintaining proper body function of animals and in reducing the negative effect on the heat stress $[17,18]$. For example, in the case of laying hens, supplementation with chromium and zinc has been shown to increase the digestibility of nutrients, alleviate effects caused by low ambient temperature [19], and decrease eggshell cracking [20]. Subject to the above, the biosorption of chromium (Cr), 
zinc $(\mathrm{Zn})$ and copper $(\mathrm{Cu})$ ions was performed in batch mode for one- and two-component solutions to determine the sorption capacity and goldenrod residues affinity for the tested microelements. The instrumental analysis of biomass before and after metal ions uptake was used for sorbent characterization and the identification of functional groups participating in metal ions binding. Analytical methods were used for quantitative analysis of the carboxyl and hydroxyl groups in the lignocellulose matrix. The mechanism of the metal ions uptake was further supported by modeling of sorption equilibrium.

Moreover, to enrich biomass in a waste-free process, postbiosorption metal solutions were used for the biofortification of cucumber sprouts. It is worth mentioning that both copper and zinc are crucial micronutrients of plant enzymatic, metabolic, and photosynthesis reactions [21, 22]. In opposite, chromium has a well-known phytotoxicity effect for plants, disordering plant germination, root and stem growth, and leaf development [23]. Thus, because of the possible usage of outlet liquid for plant fertigation, an enrichment of biomass with microelements was carried out in a fixed-bed column with identification of the breakthrough time of $\mathrm{Cr}(\mathrm{III})$.

\section{Methodology}

\section{Materials}

The biomass of plant residues was obtained as a by-product of the supercritical $\mathrm{CO}_{2}$ extraction process conducted in the New Chemical Synthesise Institute (Puławy, Poland). As received, post-extraction residues were milled by knife mill (Retsch; grindomix gm300) and sieved to obtain fractions in the range from 0.42 to $0.62 \mathrm{~mm}$.

All chemicals $\mathrm{Cu}\left(\mathrm{NO}_{3}\right)_{2} \cdot 3 \mathrm{H}_{2} \mathrm{O}$ (99.0\%; Sigma Aldrich; Germany); $\mathrm{Zn}\left(\mathrm{NO}_{3}\right)_{2} \cdot 6 \mathrm{H}_{2} \mathrm{O}$ (99.0\%; Avantor; Poland); $\mathrm{Cr}\left(\mathrm{NO}_{3}\right)_{3} \cdot 9 \mathrm{H}_{2} \mathrm{O}$ (99.0\%; Sigma Aldrich; Germany); $\mathrm{HNO}_{3}$ (69\%; Suprapur; Germany) used in this research were of analytical grade. Ultra-pure water $\left(<0.1 \mu \mathrm{S} / \mathrm{cm}\right.$, MILLI-Q ${ }^{\circledR}$ HX 7000 SD) was used to prepare the stock solution of metal salts. The initial metal concentrations in single systems were $0-5.9 ; 0-4.6 ; 0-4.7 \mathrm{mmol} / \mathrm{L}$ for $\mathrm{Cr}, \mathrm{Zn}, \mathrm{Cu}$, respectively. In each solution, the highest metal ion concentration was equal to $300 \mathrm{mg} / \mathrm{L}$. The initial $\mathrm{pH}$ values of single solutions were adjusted to 3.0, 5.6, 4.2 for $\mathrm{Cr}, \mathrm{Zn}$, and $\mathrm{Cu}$, respectively. In three binary systems: $\mathrm{Cr}-\mathrm{Cu}, \mathrm{Cu}-\mathrm{Zn}$ and $\mathrm{Zn}-\mathrm{Cr}$, the initial concentration of both metal ions varied between 0 and $6.0 \mathrm{mmol} / \mathrm{L}$ to maintain the constant molar ratio: $1: 1: 1$.

\section{Characterization of Goldenrod Mass}

FT-IR spectroscopy was used to identify the chemical groups present on the biosorbent surface. The infrared spectra of the biosorbent were recorded in the region of $4000-500 \mathrm{~cm}^{-1}$ using a Vertex $70 \mathrm{v}$ spectrometer (Bruker). The scanning electron microscope (SEM) images were recorded for surface morphology of both "as received" and metal-enriched biomasses at an acceleration voltage of $10 \mathrm{kV}$ (Microscope SEM/Ga-FIB FEI Helios NanoLab ${ }^{\mathrm{TM}}$ 600i). The microscope equipped with X-ray spectrometer (EDX) with Silicon Drift Detector was used to confirm the adsorption of metal ions by sorbent. To identify the electrical charge density $\left(\mathrm{pH}_{\mathrm{pzc}}\right)$, first, the buffer solution of $0.1 \mathrm{~mol} / \mathrm{L} \mathrm{NaNO}_{3}$ was used to adjust $\mathrm{pH}$ to a given value by the addition of $\mathrm{HNO}_{3}$ or $\mathrm{NaOH}$. Then each solution was gently stirred for 30 min with $0.2 \mathrm{~g}$ of biomass. The $\mathrm{pH}_{\mathrm{pzc}}$ was determined by Elemetron PCP-401 pH-meter. The content of carboxylic groups in the biomass was identified following [24]. Weighted mass $(0.2 \mathrm{~g})$ of biomass was shaken with $10 \mathrm{~mL}$ of $0.1 \mathrm{~N} \mathrm{NaOH}$ and $10 \mathrm{~mL}$ of acetone for $2 \mathrm{~h}$. After that, the solution was titrated with $0.1 \mathrm{~N}$ with a standard solution of $\mathrm{HCl}$ against phenolphthalein. A blank test was performed simultaneously. The number of carboxylic groups in the sample was calculated from the difference in $\mathrm{HCl}$ volumes used for the analyzed sample and the blank test. The content of carboxylic groups was calculated from the formula:

$L_{\mathrm{COOH}}=0.0001\left(V_{\mathrm{NaOH}}-V_{\mathrm{HCl}}\right) \cdot m$

where $V(\mathrm{~mL})$ is the volume of solution, and $m(\mathrm{~g})$ is the dry mass of biomass. The content of hydroxyl groups in the biomass was identified in accordance with the EU quality standard (PN-EN ISO 2554:2001).

\section{Sorption Experiments}

Adsorption isotherms were obtained by batch sorption experiments. The samples of goldenrod biomass $(0.2 \mathrm{~g})$ were gently mixed with $40 \mathrm{~mL}$ solution of single or binary component metal salts in a thermostatic shaker $(3033, \mathrm{GFL})$ at $22{ }^{\circ} \mathrm{C}$ with $30 \mathrm{rpm}$. After stirring for $8 \mathrm{~h}$, the suspension was separated from biomass by syringe filters ( $45 \mu \mathrm{m}$ cellulose acetate membrane, Millipore), acidified by the addition of conc. $\mathrm{HNO}_{3}(1.0 \mathrm{~mL} / \mathrm{L})$, and analyses for their metal content by the inductively coupled plasma optical atomic emission spectrometer (ICP-OES, Varian Vista MPX). Cr was analyzed at a wavelength of $267,716 \mathrm{~nm}, \mathrm{Cu}$ of $327,395 \mathrm{~nm}$, and $\mathrm{Zn}$ of $206,2 \mathrm{~nm}$. The amount of metal adsorbed per unit mass of adsorbent $q_{\mathrm{e}}(\mathrm{mmol} / \mathrm{g})$ was calculated from the equation:

$q_{e}=\frac{\left(C_{0}-C_{e}\right)}{2} V$

where $C_{0}(\mathrm{mmol} / \mathrm{L})$ and $C_{e}(\mathrm{mmol} / \mathrm{L})$ are the initial and the equilibrium ion concentrations, respectively. 


\section{Modelling of Biosorption Equilibrium}

The following empirical models (Eqs. 3, 4, 5) were used to evaluate the metal sorption mechanism in a single-component system:

The Langmuir model (L), which assumes homogenous sorption on the finite number of active sites with equal adsorption energy [25]:

$q_{e}=\frac{q_{m} K_{L} C_{e}}{1+K_{L} C_{e}}$

where $K_{L}(\mathrm{~L} / \mathrm{mmol})$ is the Langmuir constant associated with sorption free energy and sorbent-metal ion affinity, $q_{m}$ $(\mathrm{mmol} / \mathrm{g})$ is the maximum sorption uptake.

The Freundlich (F) model deals with the heterogeneity of the surface of sorbent towards sorbed molecule [26]:

$q_{e}=K_{F} C_{e}^{\frac{1}{n_{F}}}$

where $K_{F}$ signifies sorption capacity per unit concentration $(\mathrm{mg} / \mathrm{g}) /(\mathrm{mg} / \mathrm{L}), 1 / n_{F}$ provides information of active sites; the lesser value of $1 / n_{F}$ indicates the occurrence of heterogeneous sites and the physical sorption mechanism [27].

The Langmuir-Freundlich $(\mathrm{L}-\mathrm{F})$ model is a hybrid model that results from the combination of the previous models to circumvent the limitations of both [28]:

$q_{e}=\frac{q_{m}\left(K_{L-F} C_{e}\right)^{n_{L-F}}}{\left(K_{L-F} C_{e}\right)^{n_{L-F}}+1}$

where $K_{L-F}(\mathrm{~L} / \mathrm{mmol})$ is the Langmuir-Freundlich constant, $n_{L-F}$ represents the energetic surface heterogeneity. The model's parameters were estimated with the aid of the non-linear regression using Maple software by minimizing the Sum of the Squares of the Errors (ERRSQ):

$$
\sum_{i=1}^{p}\left(q_{e, \exp }-q_{e, \text { mod }}\right)_{i}^{2}
$$

where $p$ is the number of experimental points, $q_{e, \exp }$ and $q_{e, \text { mod }}$ are experimental and the modeling equilibrium concentrations in solid phase, respectively. The fit between experimental and calculated data for all models was evaluated using Fisher's Test (FT), standard deviation $(\sigma)$, and mean error (ME) [29].

\section{Fixed Bed Column Study}

The fixed bed experiment was conducted in an open unit run that the main element was a $16 \mathrm{~mm}$ (I.D.) glass column of $20 \mathrm{~cm}$ height (GE XK 16). The column was packed with a bed (the equivalent of $3 \mathrm{~g}$ dry material; $10 \mathrm{~cm}$ height). The trinary metal solutions of $\mathrm{Cr}: \mathrm{Cu}: \mathrm{Zn}$, with an equal concentration of each metal ion $\left(C_{i n}=0.1 \mathrm{mmol} / \mathrm{L}\right.$ of each $)$, were fed to the column by a peristaltic pump (Peristaltic pump Lab 2015; Gkisker) at the gravitational with flow rate $9.0 \mathrm{~mL} / \mathrm{min}$. Specimens of eluate were captured from the bottom of the column at specific time intervals and analyzed for metal content by the ICP-OES. The feeding of the column was continued up to $5 \mathrm{~h}$. The experiment was repeated three times.

\section{Germination Test}

Preliminary functional properties of the fertigation solution were performed in germination tests. The experiments were conducted for 10 days at $25^{\circ} \mathrm{C}$ and under uniform illumination of $2400 \mathrm{~lx}$ (16 h-day, 8 h-night). Cucumber (Cornichon de Paris) was selected as the test plant. Fifty cucumber seeds were placed on Petri dishes with moistened cotton wool (5 g). The light-protected dishes were stratified for $48 \mathrm{~h}$ at $4{ }^{\circ} \mathrm{C}$. After this time, the dishes were applied NPK fertilizer (13:13:13) in the amount of $50 \mu \mathrm{m} / \mathrm{dish}$. The fertigation solution was given to the prepared groups at the doses shown in Table 1. The moisture content of the substrate was continuously monitored during germination [30]. After 10 days, the sprouts were analyzed for growth parameters as well as chlorophyll and trace element content. The concentration of the component in the substrate. Statistical analysis was performed using Statistica software (Statsoft, Australia; Tukey's test). The Transfer Factor (TF) was determined using the equation:

$T F=\frac{C_{\text {plant }}}{C_{\text {substrate }}} \cdot 100$

where $T F$ is considered as transfer factor (\%); $C_{\text {plant }}$ represents the content of the component in the dry weight of the sprout $(\mathrm{mg} / \mathrm{kg})$ and $C_{\text {substrate }}$ provides information about the content of the component in the substrate $(\mathrm{mg} / \mathrm{kg})$;

\section{Results and Discussion}

\section{Biomass Analysis}

The scanning electron micrograph revealed the surface texture and morphology of biosorbent (Fig. 1). Sieve tubes of stalk fragments (Fig. 1A, top right corner), leaf structures (left part of the center) and fragments of ligneous plants (right bottom) confirm plant origin and the heterogeneity of the tested sample. The measured diameter of perforations (Fig. 1B) found on the biomass surface $(5.05-16.5 \mu \mathrm{m})$ is, on average, ten times larger than the estimated dimensions of xylem and phloem tissue structures [31]. This phenomenon results from the SFE processing of the biomass when 
Table 1 Plan for in vivo testing on plants

\begin{tabular}{|c|c|c|c|}
\hline \multicolumn{3}{|l|}{ Preparation } & Fertigation solution \\
\hline \multicolumn{3}{|l|}{ Plant } & Cucumber (Cornichon de Paris) \\
\hline \multicolumn{2}{|l|}{ Time } & & 10 days \\
\hline \multicolumn{2}{|l|}{ Number of seeds per dish } & & 50 \\
\hline \multicolumn{2}{|l|}{ Reference fertilizer } & & $\begin{array}{l}\text { NPK fertilizer (13:13:13) with } \\
\text { micronutrients } \\
\text { (YARA HYDROCOTE TM } \\
\text { controlled-release fertilizer) }\end{array}$ \\
\hline \multicolumn{2}{|l|}{ Dose of NPK $(13: 13: 13)$ per seed $(\mu \mathrm{g})$} & & 50 \\
\hline \multicolumn{2}{|l|}{ Repetitions } & & 3 \\
\hline \multirow[t]{7}{*}{ Dose of micronutrients per dish } & Dose & $\mathrm{Cu}$ & $\mathrm{Zn}$ \\
\hline & $\%$ & $\mu \mathrm{g}$ & $\mu \mathrm{g}$ \\
\hline & 20 & 40 & 200 \\
\hline & 50 & 100 & 500 \\
\hline & 100 & 200 & 1000 \\
\hline & 200 & 400 & 1500 \\
\hline & 300 & 600 & 3000 \\
\hline
\end{tabular}

micro-tissue damage occurs [32]. The high diameter of the biomass' perforations, in comparison to the hydrated ionic radius $(\mathrm{Cu} 4,19 \AA<\mathrm{Zn} \mathrm{4,30 \AA <}<\mathrm{Cr} 4,61 \AA)$, excludes inner diffusion resistances during ions biosorption [33].

The energy dispersive (EDS) spectra of the goldenrod residue before and after the adsorption of $\mathrm{Zn}$ (II), $\mathrm{Cu}$ (II), and $\mathrm{Cr}$ (III) are shown in Fig. 2. The biomass consisted mainly of $\mathrm{C}$ and $\mathrm{O}$. The $\mathrm{C}: \mathrm{O}$ ratio 1.8:1 is lower than in pure lignin structure (2.16:1) [34]. High surface's $\mathrm{C}$ and $\mathrm{O}$ content may correlate with the $\mathrm{C}-\mathrm{C}, \mathrm{C}-\mathrm{OH}, \mathrm{O}=\mathrm{C}-\mathrm{O}, \mathrm{HO}-\mathrm{C}, \mathrm{O}=\mathrm{C}$, and -OOC-, groups. After metal loading, the EDS analysis of biosorbent identifies the clear peaks of $\mathrm{Cr}(\mathrm{III}), \mathrm{Cu}(\mathrm{II})$, and $\mathrm{Zn}$ (II) at 5.6, 8.0, and $8.6 \mathrm{keV}$, respectively. The obtained percentage by weight of the metals follows the order: $\mathrm{Cr}>\mathrm{Cu}>\mathrm{Zn}$. The surface mapping of the received biosorbet in Fig. 3 reveals the presence of $\mathrm{Zn}$ and $\mathrm{Cu}$ and the lack of $\mathrm{Cr}$ on the surface, which is in line with the elemental composition determined by Izydorczyk et al. (2020). In opposite to $\mathrm{Cr}(\mathrm{III})$, both $\mathrm{Cu}$ (II) and $\mathrm{Zn}$ (II) are essential redox-active metals that participate in many physiological processes in plant materials [35].

The FTIR spectra of goldenrod biomass before and after metal ions sorption are shown in Fig. 4. The presence of broad absorbance in the range of 3500 to $3300 \mathrm{~cm}^{-1}$ represents carbohydrates [36]. The identified peak at $3435 \mathrm{~cm}^{-1}$ is assigned to the carboxylic stretching band or alcohol groups [37]. The peak at $2926 \mathrm{~cm}^{-1}$ may be associated with $\mathrm{O}-\mathrm{H}$ stretching of the carboxylic acid in the cell wall of the biomass. This peak is followed by the stretching at 2852 visible after metal sorption, corresponding to the aliphatic C-H group of organic chains of the cellulose [38]. The band between 1700 and $1750 \mathrm{~cm}^{-1}$ attributes to $\mathrm{C}=\mathrm{O}$ stretching vibration indicates the presence of a variety of functional groups: carboxylic, ester, quinone, conjugated aldehyde, conjugated ketone, $\alpha \beta$ unsaturated ester and aliphatic ketone [39]. The pick at $1734 \mathrm{~cm}^{-1}$ corresponds to the content of sesquiterpene lactones remaining in plant tissue after extraction [40]. The bands that appeared in the range of $1740-1050 \mathrm{~cm}^{-1}$ are related to polysaccharides with different structures and configurations. The registered band about of $1638 \mathrm{~cm}^{-1}$, relates to asymmetric and symmetric $\mathrm{C}=\mathrm{O}$ bands of carboxylic, ester or aldehyde vibrations [41, 42]. Their shift after metal ion sorption indicates a degree of carboxyl bonding. The pattern of aromatic vibration near $1600 \mathrm{~cm}^{-1}$ and $1500 \mathrm{~cm}^{-1}$, along with the peaks near $1200 \mathrm{~cm}^{-1}$ is attributed to aryl-O stretching vibration and confirms the presence of lignin. The visible and narrow peak at $1384 \mathrm{~cm}^{-1}$ appeared only after metal ions sorption and may be attributed to symmetric stretching of -COO- [43]. Two flattened peaks at 1320 and $1254 \mathrm{~cm}^{-1}$ are assigned to $\mathrm{CH}_{2}$ symmetric and $\mathrm{C}-\mathrm{H}$ bending caused by the stretching of syringyl and guaiacyl rings of lignin and lignocellulose [44]. These bands can also correspond to the $\mathrm{C}=\mathrm{O}$ stretching of ester and carboxylate groups [45]. After metal ions sorption, their position and intensity do not remain the same, further confirming the interaction of metal ions with carboxylic groups. The peak at $1052 \mathrm{~cm}^{-1}$ may indicate by the presence of $\mathrm{C}-\mathrm{O}$ vibrations caused by a large amount of polysaccharides or polysaccharide-like substances [46]. The observed vibrations in the 800-600 range relate to the presence of $\mathrm{C}-\mathrm{C}$ bonds being the core of the biomass.

The presence of carboxyl and hydroxyl groups was further confirmed by chemical analysis. The total number of identified carboxylic groups was $1.33 \mathrm{mmol} / \mathrm{g}$, while 
Fig. 1 SEM-EDS micrograph of $\mathbf{A}$ biomass and loaded with $\mathbf{B}$ $\mathrm{Zn}, \mathbf{C ~ C u}, \mathbf{D} \mathrm{Cr}$
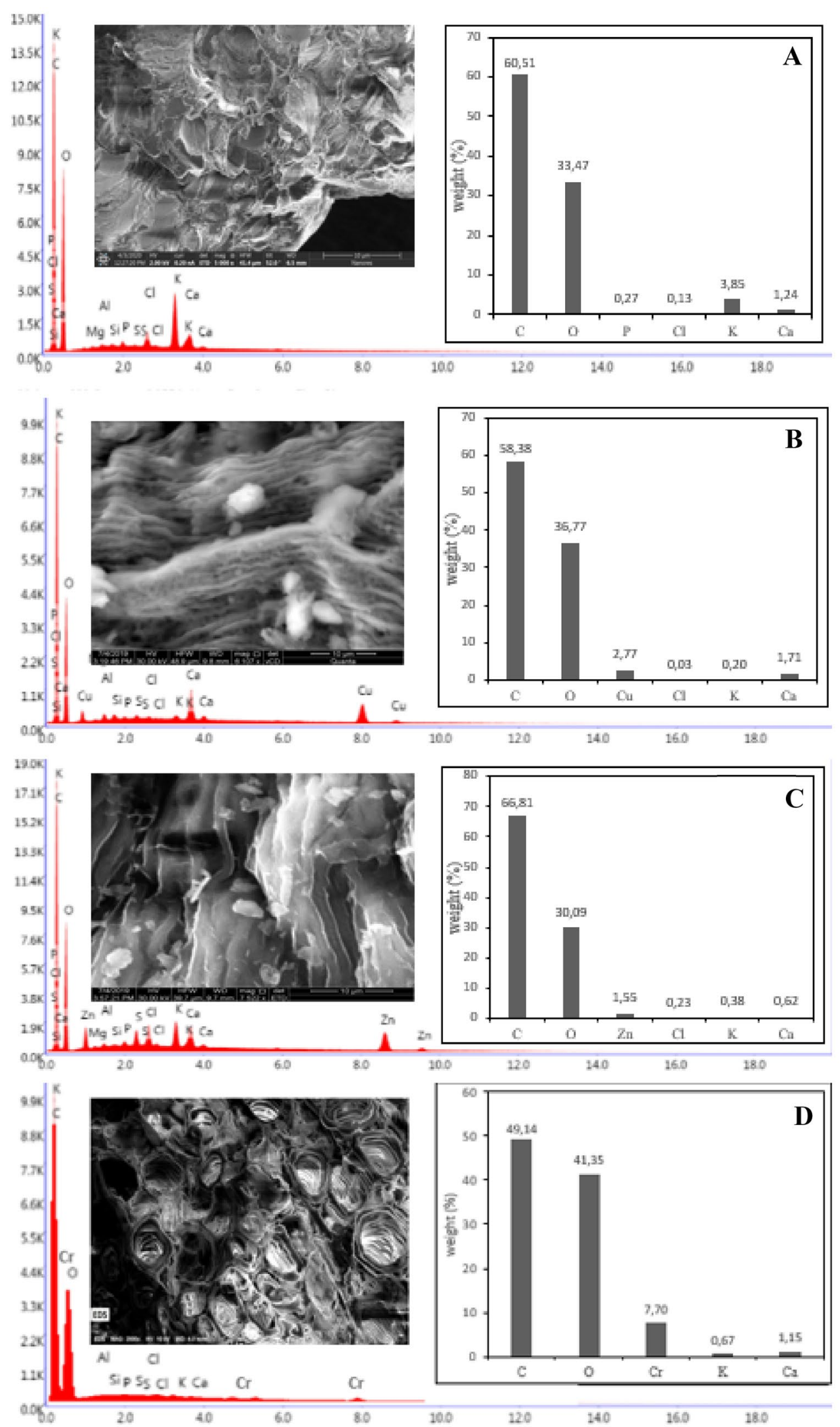
Fig. 2 Scanning electron micrography of goldenrod residues
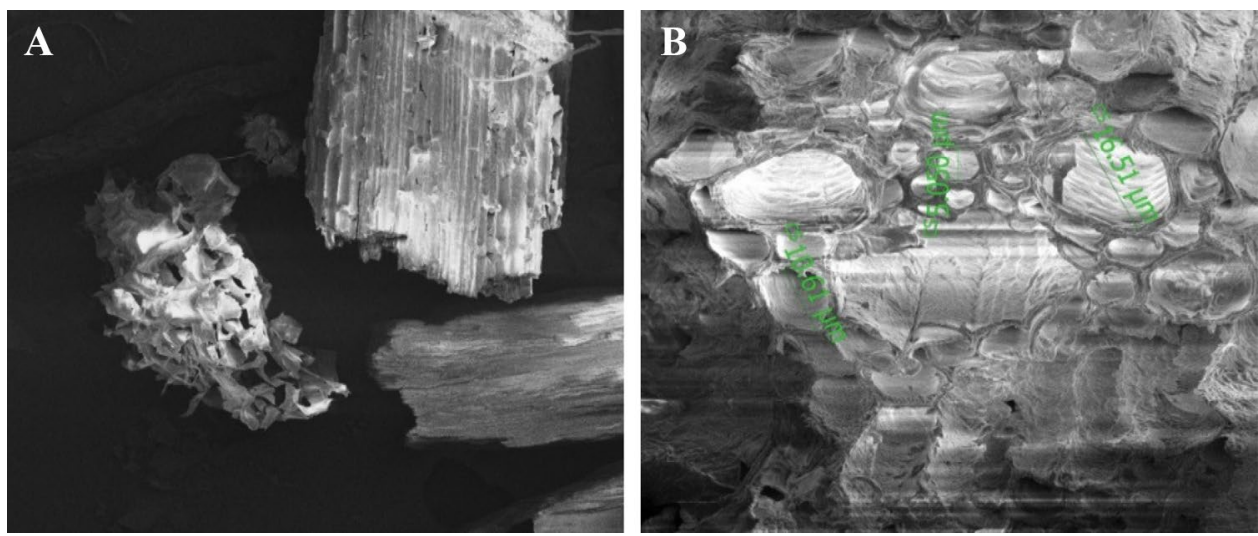
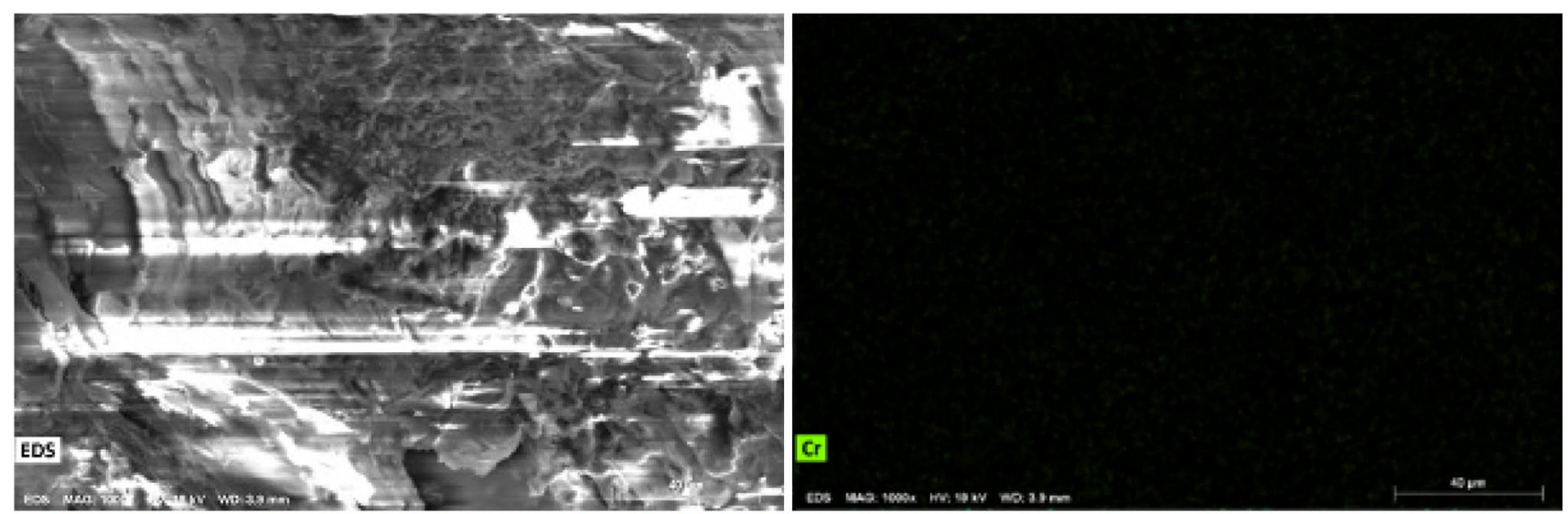

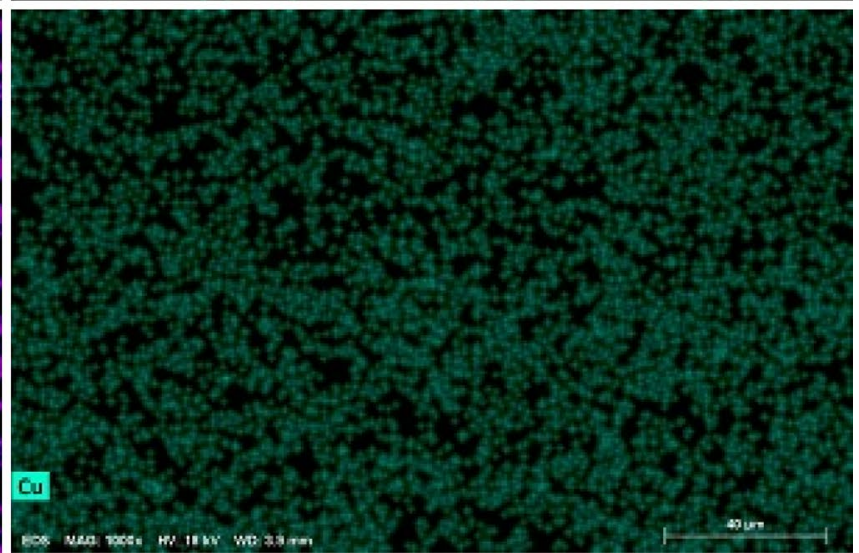

Fig. 3 Elemental dot maps of the goldenrod residue

the hydroxyl one was $0.83 \mathrm{mmol} / \mathrm{g}$. According to the above, the main mechanism of metal ions binding can be expressed as:

$n(\equiv$ biosorbent-COOH $)+\mathrm{M}^{n+} \rightarrow(\equiv \text { biosorbent-COO })_{n} \mathrm{M}+n \mathrm{H}^{+}$ where $\mathrm{M}^{n+}=\mathrm{Zn}^{2+}, \mathrm{Cu}^{2+}$, and $\mathrm{Cr}^{3+}$ ions.

The formation of $\mathrm{M}-\mathrm{O}$ bonds between metal ions and the acid functional groups of lignocellulosic sorbents was confirmed by other authors with XPS analysis [47].
Nevertheless, metal ions binding via bridging complexation, ion exchange or chelation cannot be excluded.

\section{Biosorption Isotherms}

The experimental data depicted in Fig. 5 represent the equilibrium distribution of the metal ions between the goldenrod biomass and the residual metal concentration in the liquid phase. The data exhibit nonlinearity in the uptake of every metal. As can be seen, the experimental isotherms for all 

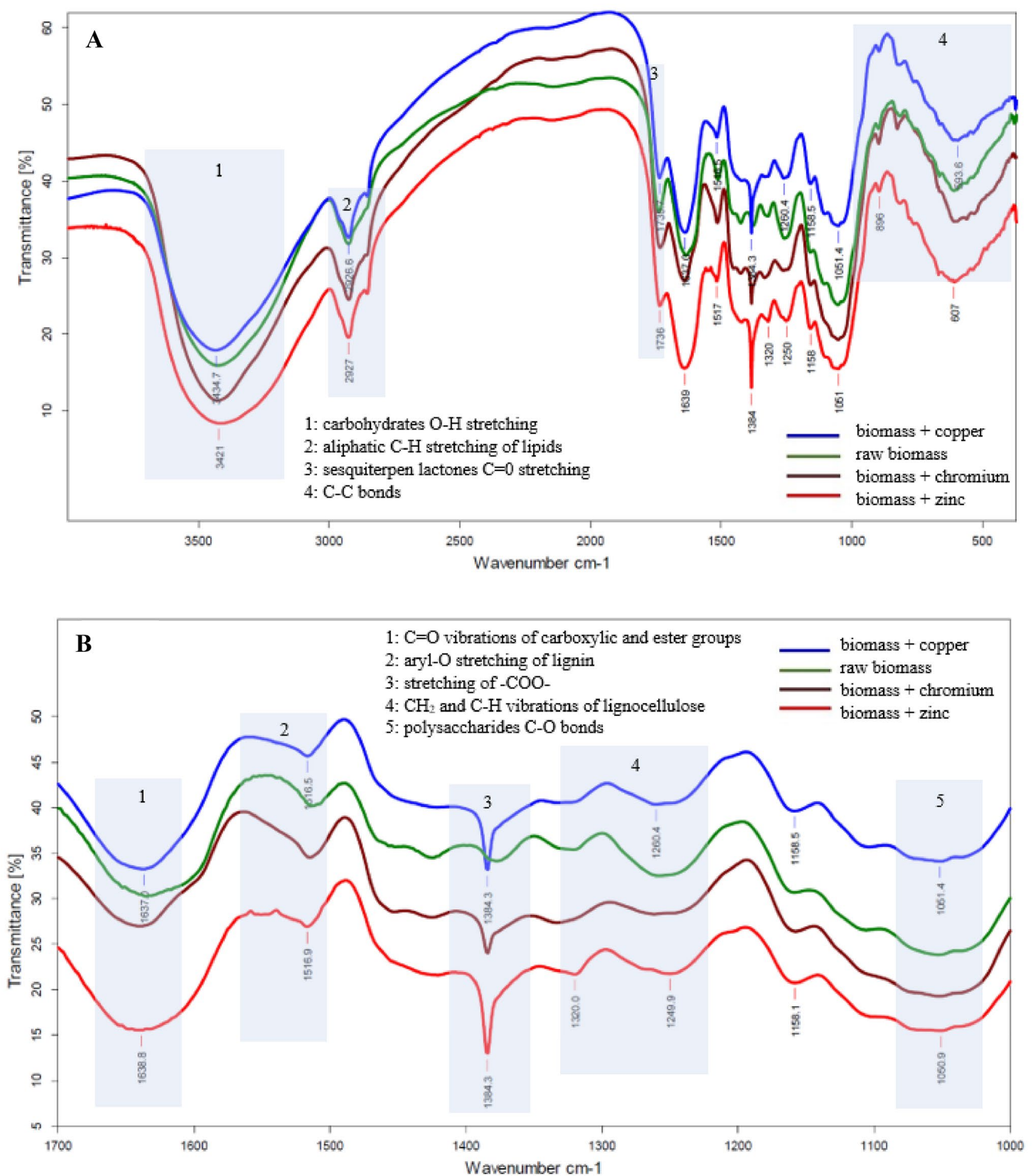

Fig. 4 FTIR spectra of goldenrod residues before and after metal sorption (A whole spectrum, B $1700-1000 \mathrm{~cm}^{-1}$ range magnification)

metal ions overlapped each other without clear identification of biomass affinity for a given metal ion. None of the isotherms reaches the sorption plateau. The values of the maximum sorption capacity obtained are close to each other.
The equilibrium $\mathrm{pH}_{\mathrm{eq}}$ values changed along with the concentration of the components and varied between $\mathrm{pH}$ 5.3-4.6 for $\mathrm{Zn}$; $\mathrm{pH}$ 4.4-3.0 for $\mathrm{Cr}$; and 5.5-3.9 for $\mathrm{Cu}$. The measured isoelectric point (pI) of goldenrod is about 5,1 . Thus, under 

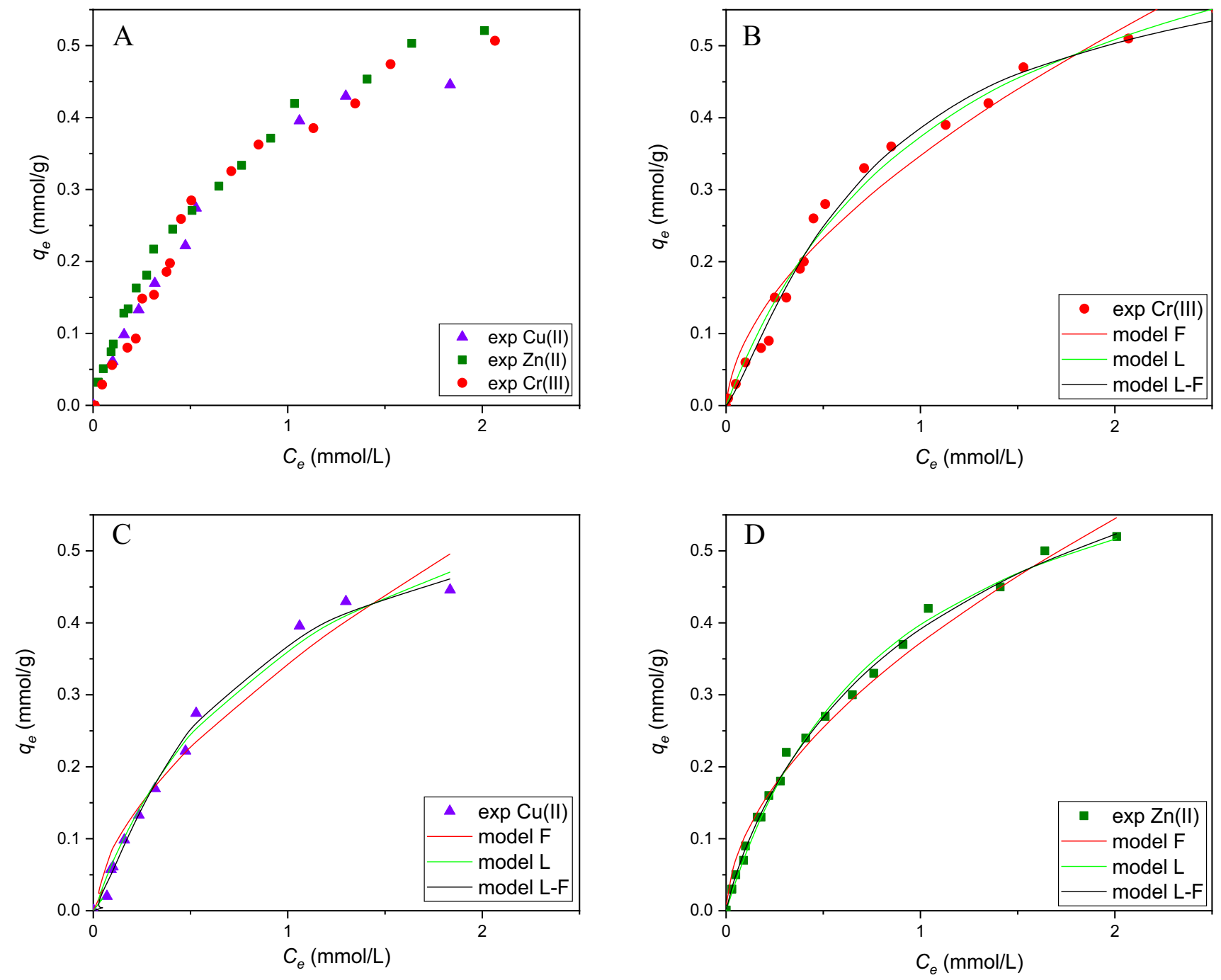

Fig. 5 Comparison between equilibrium models and experimental data obtained for single systems

the obtained $\mathrm{pH}_{\mathrm{eq}}$ ranges, most of the carboxylic acid groups were ionized $\left(\mathrm{pH}_{\mathrm{eq}}>\mathrm{pH}_{\mathrm{pzc}}\right)$, causing a strong electrostatic attraction between the sorbent surface (negatively charged) and the heavy metal ions [48].

The modeling of biosorption equilibrium was done by using three empirical equations. The values of fitting parameters are depicted in Table 1. Among the applied models, the three-parameter Langmuir-Freundlich model best fit the experimental data, as can be seen from the value of statistical tests. This model closely overlapped the Langmuir one. The maximum sorption capacities estimated from both models were higher than the obtained experimentally $\left(q_{m \text {,exp }}\right)$. The values of parameter $n_{L-F} \neq 1$ provide the multiple and energetically heterogeneous biosorption.

The comparison of $q_{m}$ obtained for single and binary solutions (Fig. 6A) identifies that the efficiency of metal ions biosorption from binary solutions is lower than from a single one. This is the case when metal ions compete for the same active sites and share them [47]. The most remarkable is the magnitude of this effect which differs for a given ionic par. The observed reduction of $\mathrm{Cr}$ (III) biosorption in the presence of $\mathrm{Zn}$ (II) and $\mathrm{Cu}$ (II) is lowered by about $20 \%$ and $40 \%$, respectively, in comparison to the single $\mathrm{Cr}$ (III) solution. In comparison, the reduction of $\mathrm{Zn}$ (II) and $\mathrm{Cu}$ (II) biosorption in the presence of $\mathrm{Cr}(\mathrm{III})$ is lowered by about 10 times for single solutions. Furthermore, the shape of the binary $\mathrm{Cr}-\mathrm{Cu}$ and $\mathrm{Zn}-\mathrm{Cr}$ isotherms (Fig. 6C, D) reveals that the equilibrium concentration of $\mathrm{Cr}$ (III) constantly increases in the whole equilibrium range. In turn, the equilibrium concentration of $\mathrm{Zn}$ (II) and $\mathrm{Cu}$ (II) increases only at low concentrations values, decreasing then sharply. In the case of the $\mathrm{Cu}-\mathrm{Zn}$ system, a clear co-sorption is seen from overlapping both isotherms at a lower concentration range. Then, the antagonistic effects of $\mathrm{Cu}$ (II) over $\mathrm{Zn}$ (II) are observed. 

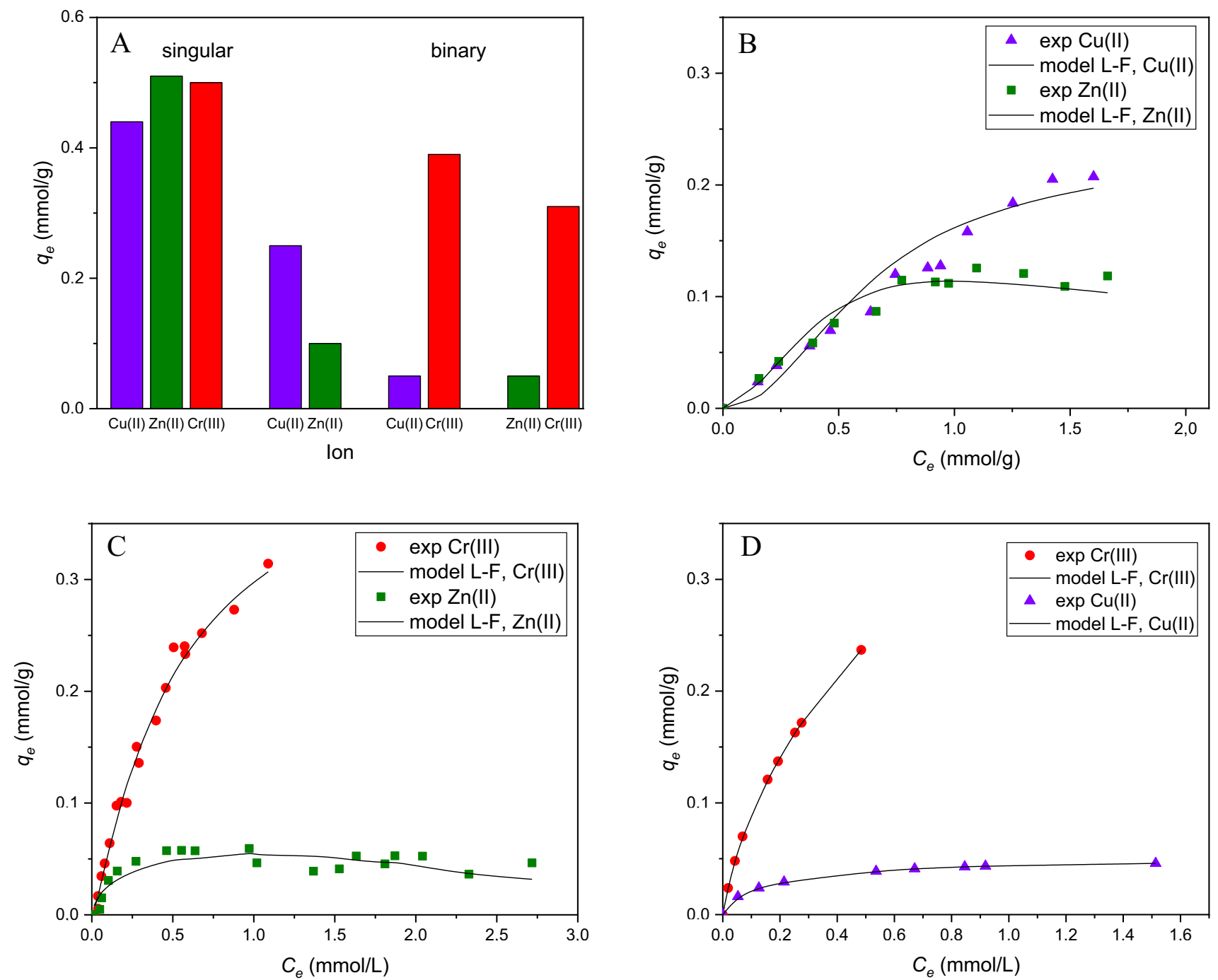

Fig. 6 Comparison between the Langmuir-Freundlich model and experimental data obtained for binary systems

$\mathrm{Cu}(\mathrm{II})$, as a more favorable ion, exchanged $\mathrm{Zn}$ (II) in active sites, decreasing its sorption. As stems from the binary isotherms, the affinity of the goldenrod residues for tested metal ions follows the order: $\mathrm{Cr}$ (III) $>\mathrm{Cu}$ (II) $>\mathrm{Zn}$ (II).

The linear extensions of the L-F model derived by adding one more concentration term were used for modeling of antagonistic sorption of heavy metal ions [47]: minimize the ERRSQ objective function across the concentration range studied [49].

The comparison of the experimental and modeling data in Fig. 6B-D demonstrates that the extended Langmuir-Freundlich model fits the binary equilibrium points reasonably well. The model's parameter values, together with statistical test results, are depicted in Table 2. Apparently, the biosorp-

$q_{e 1}=\frac{q_{m 1}\left(K_{L-F 1} C_{e 1}\right)^{n 1}}{\left(K_{L-F 1} C_{e 1}\right)^{n 1}+\left(K_{L-F 2} C_{e 2}\right)^{n 2}+1}, q_{e 2}=\frac{q_{m 2}\left(K_{L-F 2} C_{e 2}\right)^{n 2}}{\left(K_{L-F 1} C_{e 1}\right)^{n 1}+\left(K_{L-F 2} C_{e 2}\right)^{n 2}+1}$

where subscripts 1 and 2 relate to the given pair of metal ions in a binary system $(\mathrm{Cr}-\mathrm{Cu}, \mathrm{Zn}-\mathrm{Cr}, \mathrm{Cu}-\mathrm{Zn})$. In the binary equilibrium calculation procedure, the parameter sets obtained for single systems were used as an initial guess to tion capacity of $\mathrm{Cr}$ (III) is higher than that of $\mathrm{Cu}(\mathrm{II})$ and $\mathrm{Zn}$ (II), showing the higher affinity of goldenrod residue for $\mathrm{Cr}$ (III). As it steams from Table 2, Cr(III) follows homogenous sorption since $n_{L-F} \approx 1$. Nevertheless, the estimated 
Table 2 Equilibrium constants for the single biosorption of $\mathrm{Zn}(\mathrm{II}), \mathrm{Cu}(\mathrm{II})$ and $\mathrm{Cr}(\mathrm{III})$ ions on goldenrod residues

\begin{tabular}{llllllll}
\hline Metal ion & Model & $q_{m}(\mathrm{mmol} / \mathrm{g})$ & $n_{L-F}$ & $K_{L-F}(\mathrm{~L} / \mathrm{g})$ & $T F$ & $\sigma$ & ME (\%) \\
\hline $\mathrm{Zn}$ & $\mathrm{L}$ & 0.73 & n.e & 1.19 & 215.71 & 5.77 & 0.01 \\
$q_{m, \exp }=0.51$ & $\mathrm{~F}$ & n.e & 1.83 & 0.35 & 76.08 & 50.45 & 0.02 \\
$(\mathrm{mmol} / \mathrm{g})$ & $\mathrm{L}-\mathrm{F}$ & 0.78 & 0.86 & 0.87 & 287.51 & 7.50 & 0.01 \\
$\mathrm{Cu}$ & $\mathrm{L}$ & 0.71 & n.e & 1.04 & 105.69 & 31.90 & 0.02 \\
$q_{m, \exp }=0.46$ & $\mathrm{~F}$ & n.e & 0.34 & 1.67 & 28.24 & 199.55 & 0.03 \\
$(\mathrm{mmol} / \mathrm{g})$ & $\mathrm{L}-\mathrm{F}$ & 0.57 & 1.24 & 1.63 & 287.50 & 7.49 & 0.01 \\
$\mathrm{Cr}$ & $\mathrm{L}$ & 0.80 & n.e & 0.88 & 71.46 & 11.48 & 0.02 \\
$q_{m, \exp }=0.50$ & $\mathrm{~F}$ & n.e & 1.73 & 0.35 & 24.31 & 29.58 & 0.03 \\
$(\mathrm{mmol} / \mathrm{g})$ & $\mathrm{L}-\mathrm{F}$ & 0.64 & 1.25 & 1.38 & 88.40 & 13.2 & 0.02 \\
\hline
\end{tabular}

\begin{tabular}{lllllll}
\hline Binary system & $q_{m 1}$ & $n_{L-F 1}$ & $q_{m 2}$ & $n_{L-F 2}$ & $T F$ & $\sigma$ \\
\hline 12 & $(\mathrm{mmol} / \mathrm{g})$ & & $(\mathrm{mmol} / \mathrm{g})$ & & & \\
$\mathrm{Cr}-\mathrm{Cu}$ & 1.21 & 1.01 & 0.09 & 0.61 & 40.39 & 0.03 \\
$\mathrm{Zn}-\mathrm{Cr}$ & 0.13 & 0.48 & 0.85 & 1.08 & 44.27 & 0.83 \\
$\mathrm{Cu}-\mathrm{Zn}$ & 0.26 & 2.28 & 0.66 & 1.66 & 26.14 & 0.09 \\
\hline
\end{tabular}

Table 3 The LangmuirFreundlich constants for the binary biosorption on goldenrod residues values of $q_{m}$ are higher than the experimentally obtained ones (see Tables 2, 3). This results from the fact that modeling calculations were performed only for one molar ratio experimental set $(1: 1: 1)$ and the obtained isotherms' curves had a grove up tendency.

\section{Triplee-Biosorption Breakthrough Curves}

The envisaged higher affinity of the biomass for $\mathrm{Cr}(\mathrm{III})$ than $\mathrm{Cu}(\mathrm{II})$ and $\mathrm{Zn}$ (II) creates an opportunity to the enrichment of the SFE residue in a close free-waste processing cycle. Thus, the competitive biosorption of $\mathrm{Cr}(\mathrm{III}), \mathrm{Cu}$ (II) and $\mathrm{Zn}$ (II) ionic mixture under continuous conditions was evaluated on a laboratory scale. The breakthrough curves depicted in Fig. 7 are expressed in terms of normalized concentration, defined as the ratio of effluent metal concentration to influent metal concentration $\left(C / C_{i n}\right)$, as a time (t) function. As can be observed from the plots grow up, all breakthroughs obtained have a flatter concave shape. The fastest bed saturation was achieved for $\mathrm{Zn}(\mathrm{II})$. In the case of this ion, $C / C_{i n}>1$, which identified its replacement by competitive ions. The metal ions breakthrough points follow the order: $\mathrm{Zn}(5 \mathrm{~min})>\mathrm{Cu}$ (9 $\mathrm{min})>\mathrm{Cr}(25 \mathrm{~min})$. The $\mathrm{Cr}(\mathrm{III})$ breakthrough point is when the biomass enrichment process should be stopped to prohibit $\mathrm{Cr}$ (III) appearance in the liquid outlet. As can be seen from the picture magnification, up to $25 \mathrm{~min}$ of liquid flow $\mathrm{Cr}$ (III) is sorbed on biomass, while the content of $\mathrm{Cu}(\mathrm{II})$ and $\mathrm{Zn}$ (II) in the liquid outlet tends to increase. The adsorption loading of metal ions up to 25 min of filtration (magnification on Fig. 7) was obtained by integration of the area under the breakthrough curve, at $C_{i n}$ feeding concentration and $\overline{\mathrm{V}}$ flow rate, by using the following equations:

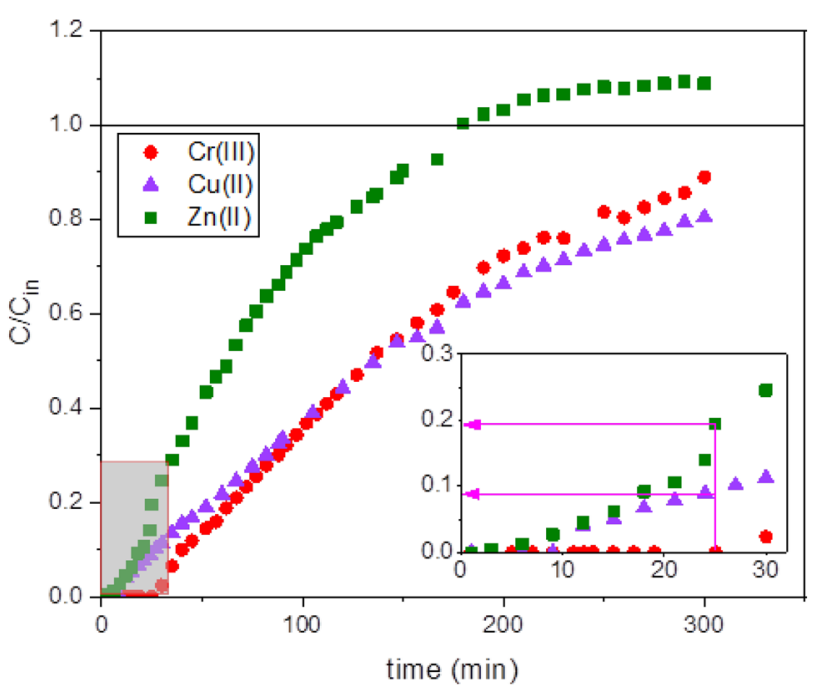

Fig. 7 Breakthrough curves for triple metal ions biosorption

$q_{t}=\frac{\bar{V}}{m_{b}} \int_{t=0}^{t=25}\left(C_{i n}-C(t)\right) d t$

$q_{t} \approx \frac{\bar{V}}{m_{b}} \sum_{i=0}^{p}\left(C_{i}-\bar{C}\right) \cdot\left(t_{i+1}-t_{i}\right)$ and $\bar{C}=\left(C_{i+1}+C_{i}\right) / 2$

where $t(\min )$ is time, $m_{b}(\mathrm{~g})$ is mass of bed, $\bar{V}$ is volumetric flow rate $(\mathrm{mL} / \mathrm{min}), \mathrm{C}_{\mathrm{i}}$ is an effluent concentration $(\mathrm{mmol} / \mathrm{L})$ at given $i$.

The calculated amount of metal ions sorbed by the biomass in the first $25 \mathrm{~min}$ of the process, equals $0.39 \mathrm{mgCr} / \mathrm{g}$ 
$(0.0075 \mathrm{mmol} / \mathrm{g}), 0.43 \mathrm{mgCu} / \mathrm{g}(0.0067 \mathrm{mmol} / \mathrm{g})$ and 0.41 $\mathrm{mgZn} / \mathrm{g}(0.0063 \mathrm{mmol})$. The obtained biomass enriched with microelements can be used as a feed additive, for e.g., chickens. As demonstrated by scientific studies, the chromium content in a food additive positively affected laying eggs efficiency [50] and on chicken growth [51]. Considering the obtained values of $q_{\mathrm{t}}$ for $\mathrm{Cu}$ and $\mathrm{Zn}$, their content did not exceed the UE regulation levels allowed in poultry feed (35 and $250 \mathrm{mg} / \mathrm{kg}$, respectively) [52]. Furthermore, the usage of enriched goldenrod residue as a food additive can enrich poultry feed with cellulose, the main fiber component.

The concentration of $\mathrm{Cr}, \mathrm{Cu}$, and $\mathrm{Zn}$ in the outlet solution, which was collected over 25 min of filtration, was calculated from the equation:

$C_{t}=\frac{\bar{V} \cdot \sum_{i=0}^{p}\left(\frac{C_{i+1}+C_{i}}{2}\right) \cdot\left(t_{i+1}-t_{i}\right)}{V_{t}}$

where $V_{\mathrm{t}}(\mathrm{mL})$ is the volume of effluent collected during 25 min of filtration.

The values obtained were as follows: $0 \mathrm{mgCr} / \mathrm{L}, 0.68$ $\mathrm{mgCu} / \mathrm{L}$, and $0.80 \mathrm{mgZn} / \mathrm{L}$. The latter two amounts are higher than recommended in commercially available liquid fertilizers for fertigation $(0.12 \mathrm{mgCu} / \mathrm{L}$ and $0.35 \mathrm{mgZn} / \mathrm{L})$ but lower than recommended for foliar fertilizers (Mikroplus; Intermag). Obviously, for lower concentrations of all metals in column inlet, the binding sides would be occupied slower and more time would be needed to saturate the column bed. However, to delay the breakthrough time of $\mathrm{Cr}(\mathrm{III})$ in relation to the divalent ions, it would be more appropriate to reduce its initial concentration in the inlet solution.

The research indicates the potential for biomass enrichment with metal ions in a closed-loop cycle in the fertigation and feed additives industry. For example (Fig. 8), a

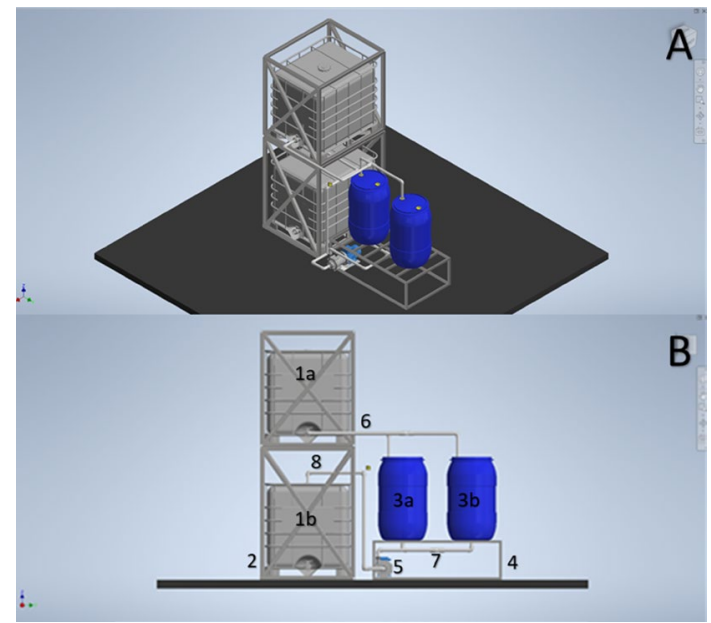

Fig. 8 Model of a garden-scale biosorption plant (Inventor 2021; Autodesk, USA)

garden-scale biosorption tank can consist of two intermediate bulk containers, placed one on top of the other. The top container would act as a rainwater collector with dissolved salt of microelements. It should have a valve to gravitationally feed the bottom container. The latter would act as a fixed bed reactor filled with any lignocellulose residues. The bottom container should be equipped with two punctured shelfs allowing bed packing and preventing biomass floating and with an outlet valve. After filtration, biomass ought to be sun-dried to prevent rotting, while the collected outlet solution, after dilutions, is used for the plants fertigation.

To potentially reduce the construction costs, the selection of the plant components was made based on commercially available components. The model consists of two 1000L Mauzer tanks (1a and 1b) with support system (2), two polypropylene tanks ( $3 \mathrm{a}$ and $3 \mathrm{~b}$ ), a frame supporting

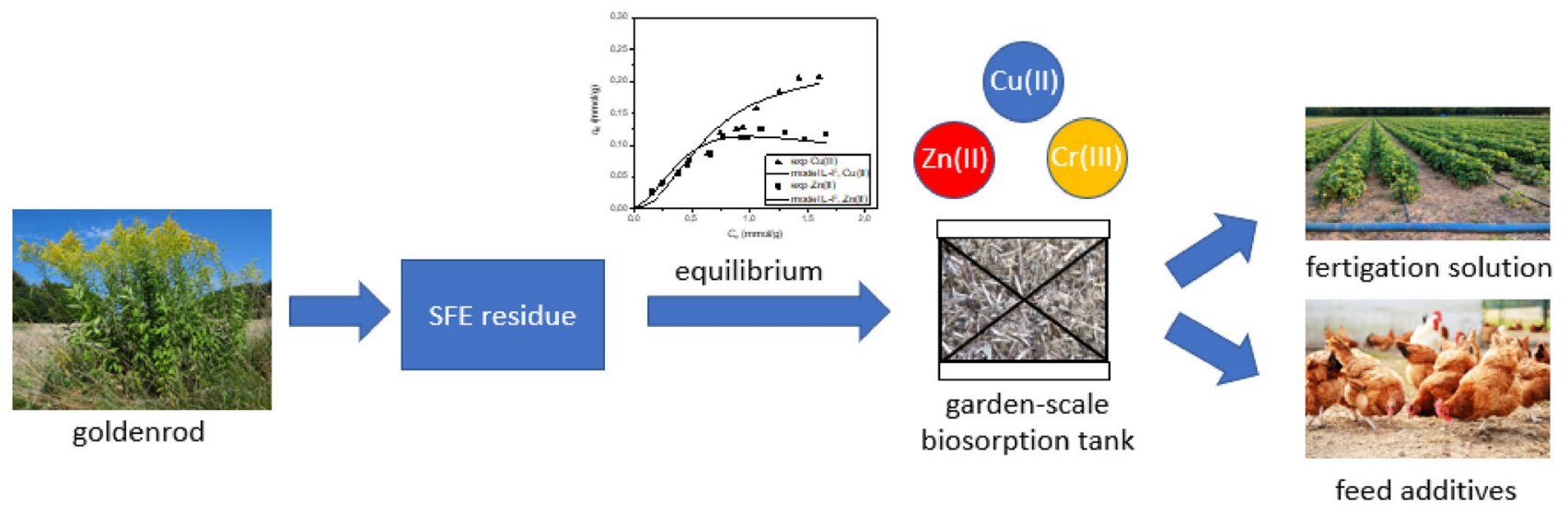

Fig. 9 Ideological diagram of work 
Table 4 Effect of micronutrient dose on growth parameters of cucumber sprouts (0-unfertilized group, $\mathrm{KN}$ - group fertilized with commercial formulation, 20-300 groups fertilized with fertigation solution)

\begin{tabular}{|c|c|c|c|}
\hline $\begin{array}{l}\text { Dose } \\
\%\end{array}$ & $\begin{array}{l}\text { Fresh mass } \\
\mathrm{g}\end{array}$ & $\begin{array}{l}\text { Chlorophyll } \\
\mathrm{mg} / \mathrm{m}^{2}\end{array}$ & $\begin{array}{l}\text { Steam lenght } \\
\mathrm{cm}\end{array}$ \\
\hline 0 & $8.23 \pm 0.114^{\mathrm{a}, \mathrm{b}, \mathrm{c}, \mathrm{d}, \mathrm{e}}$ & $538 \pm 52.6^{\mathrm{a}, \mathrm{b}, \mathrm{c}}$ & $1.82 \pm 0.324^{\mathrm{a}, \mathrm{b}, \mathrm{c}, \mathrm{d}, \mathrm{e}}$ \\
\hline $100(\mathrm{KN})$ & $10.7 \pm 0.164^{\mathrm{a}, \mathrm{f}, \mathrm{g}, \mathrm{h}}$ & $507 \pm 54.0^{\mathrm{d}, \mathrm{e}, \mathrm{f}, \mathrm{g}, \mathrm{h}}$ & $2.71 \pm 0.372^{\mathrm{a}, \mathrm{f}, \mathrm{g}, \mathrm{h}}$ \\
\hline 20 & $11.3 \pm 0.232^{\mathrm{b}, \mathrm{i}}$ & $609 \pm 34.9^{\mathrm{a}, \mathrm{d}}$ & $2.68 \pm 0.370^{\mathrm{b}, \mathrm{l}, \mathrm{m}, \mathrm{n}}$ \\
\hline 50 & $11.8 \pm 0.216^{\mathrm{c}, \mathrm{f}, \mathrm{j}, \mathrm{k}}$ & $598 \pm 26.1^{\mathrm{b}, \mathrm{e}}$ & $3.03 \pm 0.322^{\mathrm{c}, \mathrm{o}, \mathrm{p}, \mathrm{r}}$ \\
\hline 100 & $12.0 \pm 0.021^{\mathrm{d}, \mathrm{g}, \mathrm{l}, \mathrm{m}}$ & $592 \pm 34.8^{\mathrm{f}}$ & $3.55 \pm 0.323^{\mathrm{d}, \mathrm{f}, \mathrm{l}, \mathrm{o}, \mathrm{s}, \mathrm{t}}$ \\
\hline 200 & $10.6 \pm 0.427^{\mathrm{e}, \mathrm{h}, \mathrm{j}, \mathrm{l}, \mathrm{n}}$ & $609 \pm 27.5^{\mathrm{c}, \mathrm{g}}$ & $2.29 \pm 0.342^{\mathrm{e}, \mathrm{g}, \mathrm{m}, \mathrm{p}, \mathrm{s}, \mathrm{u}}$ \\
\hline 300 & $7.70 \pm 0.21^{\mathrm{i}, \mathrm{k}, \mathrm{m}, \mathrm{n}}$ & $593 \pm 41.7^{\mathrm{h}}$ & $1.70 \pm 0.267^{\mathrm{h}, \mathrm{n}, \mathrm{r}, \mathrm{t}, \mathrm{u}}$ \\
\hline
\end{tabular}

a,b,c... Statistically significant differences relative to the zero and reference groups-Tukey test ( $\mathrm{p}<0.05$, vertical comparison)

the tank (4), a centrifugal pump (5) and a set of valves and pipes transporting the fluids $(6,7,8)$.

The proposed residue valorization is an energy-free process, using rainwater as a renewable liquid, which would allow achieving circular economy status for the SFE technique (Fig. 9).

\section{Seeds Germination and Plant Growth}

Germination tests were conducted at a laboratory scale to evaluate crop promotion products for phytotoxicity and bioavailability of elements [53]. Germination is a crucial stage of plant growth that is influenced by both internal and external factors. The most important factors of the process include moisture, temperature and light, providing these conditions allows for objective assessment of the effectiveness of formulations [54]. This process causes a number of biochemical changes inside the seed and the accumulation of health-promoting components. Extremely high contributions in the initial stages of growth are micronutrients from the group of $\mathrm{Cu}, \mathrm{Mn}$, and $\mathrm{Zn}$, which affect the plant's sustainable development [55].

Analyzed parameters of cucumber sprout growth (stem length, fresh sprout weight, chlorophyll content) are presented in Table 4 and Fig. 10. The highest fresh sprout mass $(12.0 \mathrm{~g})$ was achieved in the group fertilized with a dose of $100 \%$ of micronutrient demand. The obtained sprout mass was about $13 \%$ higher compared to the group fertilized with a commercial product. Groups fertigated with doses above the optimum showed a phytotoxic effect. A similar effect can be observed in the case of stem length, where maximum length was found in a group with an applied dose of $100 \%$. For mass and stem length, statistically significant differences were found between almost all groups. A different effect was observed for chlorophyll content, where statistically significant differences occurred only between the zero and control groups and the groups fertigated with the solution after the biosorption process. This effect can be correlated with the high zinc content of fertigated sprouts (Table 5). This element plays a significant role in the structure of chloroplasts [56].

The crucial parameter in assessing the bioavailability of nutrient formulations is TF, which describes the content of micronutrients in the plant relative to the amount applied to the substrate [57]. The coefficient decreases with increasing micronutrient dose, which is closely related to the plant's limited demand for selected micronutrients (Table 4) [58]. At the optimum dose, the TF was twice as high as the group fertilized with commercial fertilizer. After biosorption, the components present in the solution are in ionic form, which is the most bioavailable form, significantly affecting their transfer and accumulation in the plant [59]. Statistically significant differences occurred between almost all groups, excluding the control group and selected fertigated groups.

Preliminary evaluation of solution utilization efficiency after the biosorption process confirmed the possibility of waste management for agricultural purposes. It can be concluded that the high bioavailability of components in the ionic form leads to biofortification of cucumber sprouts, which furtherly can result in the cultivation of highly nutritious functional foods [60].

\section{Summary}

The SFE goldenrod residues are lignocellulose materials with a high content of carboxyl and hydroxyl functional groups suitable for metal ions binding. Equilibrium studies for single metal solutions did not identify any preferred sorption of tri or divalent ions. The higher affinity of biomass for $\mathrm{Cr}(\mathrm{III})$ has been proved only after the binary equilibrium tests. The obtained sequence of affinity: $\mathrm{Cr}(\mathrm{III})>>\mathrm{Cu}(\mathrm{II})>\mathrm{Zn}$ (II) was furtherly confirmed in the fix-bed study. The breakthrough time for $\mathrm{Cr}$ (III) was the longest compared to other ions, and the process termination ensured the absence of $\mathrm{Cr}$ (III) in the outlet solution. The metal ions content in enriched biomass for $\mathrm{Cr}, \mathrm{Cu}$, and $\mathrm{Zn}$ was equal: $0.0075,0.0067$ and $0.0063 \mathrm{mmol} / \mathrm{g}$. Due to the presence of microelements and cellulose, the enriched biomass can be applied as a feed additive. The collected filtration solution contained $0.011 \mathrm{mmol} \mathrm{Cu} / \mathrm{L}$ and $0.012 \mathrm{mmol} \mathrm{Zn/L} \mathrm{can} \mathrm{be} \mathrm{used} \mathrm{for}$ the plants fertigation. Using the post-sorptive solution as a source of micronutrients for plants showed significant effects on growth parameters compared to groups fertilized with commercial formulation (13\% higher sprout mass). 
Fig. 10 Effect of micronutrients dose on stem length (A) and chlorophyll content $(\mathbf{B})$ of cucumber sprouts (0-unfertilized group, $\mathrm{KN}$ - group fertilized with commercial formulation, 20-300 groups fertilized with fertigation solution)
Table 5 Effect of micronutrient dose on micronutrient content in sprout and Transfer Factor (0-unfertilized group, $\mathrm{KN}$ - group fertilized with commercial formulation, groups fertilized with fertigation solution)
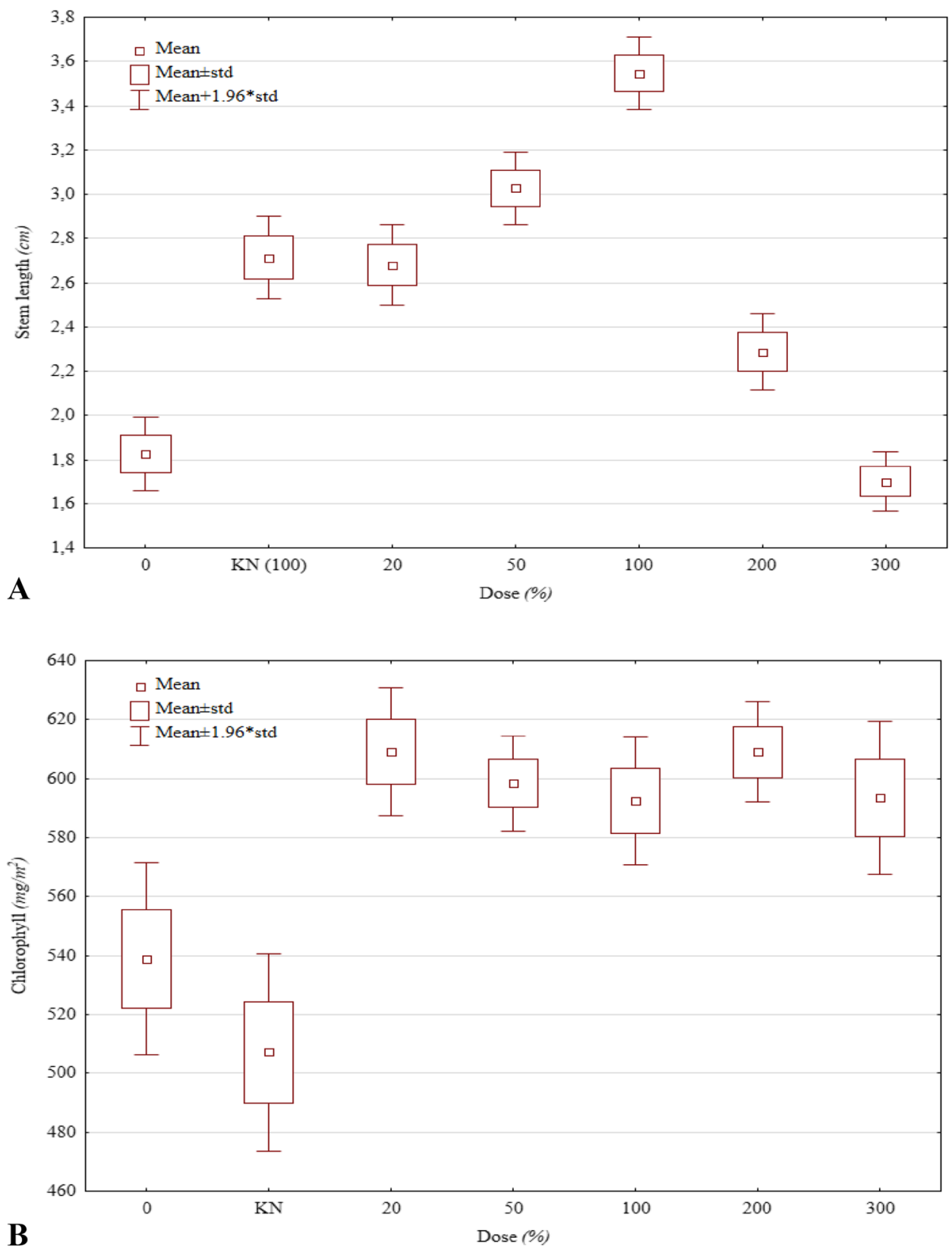

\begin{tabular}{|c|c|c|c|c|}
\hline \multirow[t]{2}{*}{ Dose } & \multicolumn{2}{|l|}{ Content } & \multicolumn{2}{|l|}{$\mathrm{TF}$} \\
\hline & $\mathrm{mg} / \mathrm{kg}$ & & $\%$ & \\
\hline$\%$ & $\mathrm{Cu}$ & $\mathrm{Zn}$ & $\mathrm{Cu}$ & $\mathrm{Zn}$ \\
\hline 0 & $7.81 \pm 0.628^{\mathrm{a}, \mathrm{b}, \mathrm{c}, \mathrm{d}, \mathrm{e}, \mathrm{f}}$ & $44.3 \pm 1.93^{\mathrm{a}, \mathrm{b}, \mathrm{c}, \mathrm{d}, \mathrm{e}, \mathrm{f}}$ & - & - \\
\hline $100(\mathrm{KN})$ & $31.1 \pm 0.469^{\mathrm{a}, \mathrm{g}, \mathrm{h}, \mathrm{i}, \mathrm{j}}$ & $152 \pm 0.61^{\mathrm{a}, \mathrm{g}, \mathrm{h}, \mathrm{i}, \mathrm{j}}$ & $10.3 \pm 0.156^{\mathrm{a}, \mathrm{b}, \mathrm{c}, \mathrm{d}}$ & $10.1 \pm 0.041^{\mathrm{a}, \mathrm{b}, \mathrm{c}, \mathrm{d}}$ \\
\hline 20 & $35.2 \pm 0.640^{\mathrm{b}, \mathrm{k}, \mathrm{l}, \mathrm{m}, \mathrm{n}}$ & $173 \pm 1.16^{\mathrm{b}, \mathrm{k}, \mathrm{l}, \mathrm{m}}$ & $62.7 \pm 1.144^{\mathrm{a}, \mathrm{e}, \mathrm{f}, \mathrm{g}, \mathrm{h}}$ & $61.9 \pm 0.413^{\mathrm{a}, \mathrm{e}, \mathrm{f}, \mathrm{g}, \mathrm{h}}$ \\
\hline 50 & $47.2 \pm 0.696^{\mathrm{c}, \mathrm{g}, \mathrm{k}, \mathrm{o}, \mathrm{p}, \mathrm{r}}$ & $218 \pm 3.54^{\mathrm{c}, \mathrm{g}, \mathrm{n}, \mathrm{o}, \mathrm{p}}$ & $78.2 \pm 1.153^{\mathrm{b}, \mathrm{e}, \mathrm{i}, \mathrm{j}, \mathrm{k}}$ & $36.1 \pm 0.587^{\mathrm{b}, \mathrm{e}, \mathrm{i}, \mathrm{j}, \mathrm{k}}$ \\
\hline 100 & $61.8 \pm 2.260^{\mathrm{d}, \mathrm{h}, \mathrm{l}, \mathrm{o}, \mathrm{s}, \mathrm{t}}$ & $288 \pm 14.1^{\mathrm{d}, \mathrm{h}, \mathrm{k}, \mathrm{n}, \mathrm{r.s}}$ & $54.3 \pm 1.984^{\mathrm{c}, \mathrm{f}, \mathrm{i}, \mathrm{l}, \mathrm{m}}$ & $25.2 \pm 1.234^{\mathrm{c}, \mathrm{f}, \mathrm{i}, \mathrm{l}}$ \\
\hline 200 & $133.9 \pm 4.331^{\mathrm{e}, \mathrm{i}, \mathrm{m}, \mathrm{p}, \mathrm{s}}$ & $457 \pm 22.3^{\mathrm{e}, \mathrm{i}, \mathrm{l}, \mathrm{o}, \mathrm{r}}$ & $26.7 \pm 0.862^{\mathrm{d}, \mathrm{g}, \mathrm{j}, \mathrm{l}, \mathrm{n}}$ & $24.3 \pm 1.185^{\mathrm{d}, \mathrm{g}, \mathrm{j}, \mathrm{m}}$ \\
\hline 300 & $133.6 \pm 5.384^{\mathrm{f}, \mathrm{j}, \mathrm{n}, \mathrm{r}, \mathrm{t}}$ & $443 \pm 15.0^{\mathrm{f}, \mathrm{j}, \mathrm{m}, \mathrm{p}, \mathrm{s}}$ & $13.3 \pm 0.537^{\mathrm{h}, \mathrm{k}, \mathrm{m}, \mathrm{n}}$ & $8.84 \pm 0.300^{\mathrm{h}, \mathrm{k}, \mathrm{l}, \mathrm{m}}$ \\
\hline
\end{tabular}

a,b,c... Statistically significant differences relative to the zero and reference groups-Tukey test $(\mathrm{p}<0.05$, vertical comparison) 


\section{Conclusions}

The enrichment of the SFE residue with microelements with a view of its use as a food additive closes the loop of the goldenrode plant processing cycle. Furthermore, the utilization of post-biosorption metal solutions for fortification of plants makes the enrichment process waste-free. Due to the toxic effect of chromium on plant, the enrichment of biomass with $\mathrm{Cr}, \mathrm{Cu}$, and $\mathrm{Zn}$ ions should be performed in a fixedbed column, which enables biosorption termination when $\mathrm{Cr}$ appears in column outlet. Due to this, it is possible to obtain two products: enriched in $\mathrm{Cr}, \mathrm{Cu}$, and $\mathrm{Zn}$ food additive, and fertigation liquid containing $\mathrm{Cu}$ and $\mathrm{Zn}$. The closed circuit of microelements classifies the presented technique as environmentally friendly according to European Union standards.

Acknowledgements This project is financed in the framework of grant entitled:" Cultivated plants and natural products as a source of biologically active sub-stances assign to the production of cosmetic and pharmaceutical products as well as diet supplements" (No. BIOSTRATEG2/298205/9/NCBR/2016) attributed by the National Centre for Research and Development.

Author Contributions All authors contributed to the study's conception and design. Material preparation, data collection and analysis were performed by BL, and DS. BL wrote the first draft of the manuscript and all authors commented on previous versions of the manuscript. All authors read and approved the final manuscript.

Funding This project is financed in the framework of grant entitled:" Cultivated plants and natural products as a source of biologically active sub-stances assign to the production of cosmetic and pharmaceutical products as well as diet supplements" (no.BIOSTRATEG2/298205/9/ NCBR/2016) attributed by the National Centre for Research and Development.

Data Availability The data that support the findings of this study are available on request from the corresponding author.

Code Availability Not applicable.

\section{Declarations}

Conflict of interest The authors declare that they have no known competing financial interests or personal relationships that could have appeared to influence the work reported in this paper.

Open Access This article is licensed under a Creative Commons Attribution 4.0 International License, which permits use, sharing, adaptation, distribution and reproduction in any medium or format, as long as you give appropriate credit to the original author(s) and the source, provide a link to the Creative Commons licence, and indicate if changes were made. The images or other third party material in this article are included in the article's Creative Commons licence, unless indicated otherwise in a credit line to the material. If material is not included in the article's Creative Commons licence and your intended use is not permitted by statutory regulation or exceeds the permitted use, you will need to obtain permission directly from the copyright holder. To view a copy of this licence, visit http://creativecommons.org/licenses/by/4.0/.

\section{References}

1. Ritzén, S., Sandström, G.Ö.: Barriers to the circular economy integration of perspectives and domains. In: Procedia CIRP (2017)

2. Michalak, I., Godlewska, K., Marycz, K.: Biomass enriched with minerals via biosorption process as a potential ingredient of horse feed. Waste Biomass Valoriz. 10, 1-16 (2018). https://doi.org/10. 1007/s12649-018-0351-5

3. Witkowska, Z., Świniarska, M., Korczyński, M., Opaliński, S., Konkol, D., Michalak, I., Saeid, A., Mironiuk, M., Chojnacka, K.: Biofortification of hens' eggs with microelements by innovative bio-based dietary supplement. J. Anim. Physiol. Anim. Nutr. (Berl) 103, 485-492 (2019). https://doi.org/10.1111/jpn.13027

4. Witkowska, Z., Chojnacka, K., Korczyński, M., Świniarska, M., Saeid, A., Opaliński, S., Dobrzański, Z.: Soybean meal enriched with microelements by biosorption: a new biological feed supplement for laying hens. Part I. Performance and egg traits. Food Chem. 151, 86-92 (2014). https://doi.org/10.1016/j.foodchem. 2013.11.023

5. Saeid, A., Chojnacka, K., Opaliński, S., Korczyński, M.: Biomass of Spirulina maxima enriched by biosorption process as a new feed supplement for laying hens. Algal Res. 19, 342-347 (2016). https://doi.org/10.1016/j.algal.2016.02.008

6. Michalak, I., Chojnacka, K., Dobrzański, Z., Górecki, H., Zielińska, A., Korczyński, M., Opaliński, S.: Effect of macroalgae enriched with microelements on egg quality parameters and mineral content of eggs, eggshell, blood, feathers and droppings. J. Anim. Physiol. Anim. Nutr. (Berl) 95, 374-387 (2011). https:// doi.org/10.1111/j.1439-0396.2010.01065.x

7. Saeid, A., Chojnacka, K., Korczyński, M., Korniewicz, D., Dobrzański, Z.: Biomass of Spirulina maxima enriched by biosorption process as a new feed supplement for swine. J. Appl. Phycol. 25, 667-675 (2013). https://doi.org/10.1007/ s10811-012-9901-6

8. European Parliament and Council: Regulation (EC) No 767/2009 of the European Parliament and of the Council of 13 July 2009 on the placing on the market and use of feed. Off. J. Eur. Union. L 229/1-28 (2009)

9. Kraujalienė, V., Pukalskas, A., Venskutonis, P.R.: Biorefining of goldenrod (Solidago virgaurea L.) leaves by supercritical fluid and pressurized liquid extraction and evaluation of antioxidant properties and main phytochemicals in the fractions and plant material. J. Funct. Foods 37, 200-208 (2017). https://doi.org/10. 1016/j.jff.2017.07.049

10. Gao, D.W., Hu, Q., Pan, H., Jiang, J., Wang, P.: High-capacity adsorption of aniline using surface modification of lignocellulosebiomass jute fibers. Bioresour. Technol. 193, 507-512 (2015). https://doi.org/10.1016/j.biortech.2015.06.138

11. Sarada, B., Krishna Prasad, M., Kishore Kumar, K., Murthy, C.V.R.: Biosorption of $\mathrm{Cd}+2$ by green plant biomass, Araucaria heterophylla: characterization, kinetic, isotherm and thermodynamic studies. Appl. Water Sci. 7, 3483-3496 (2017). https://doi. org/10.1007/s13201-017-0618-1

12. Meseguer, V.F., Ortuño, J.F., Aguilar, M.I., Pinzón-Bedoya, M.L., Lloréns, M., Sáez, J., Pérez-Marín, A.B.: Biosorption of cadmium (II) from aqueous solutions by natural and modified non-living leaves of Posidonia oceanica. Environ. Sci. Pollut. Res. 23, 24032-24046 (2016). https://doi.org/10.1007/s11356-016-7625-x

13. Zhao, X., Zhu, H., Chen, J., Ao, Q.: FTIR, XRD and SEM analysis of ginger powders with different size. J. Food Process. Preserv. 39, 2017-2026 (2015). https://doi.org/10.1111/jfpp.12442

14. Wu, Y., Zhang, S., Guo, X., Huang, H.: Adsorption of chromium(III) on lignin. Bioresour. Technol. 99, 7709-7715 (2008). https://doi.org/10.1016/j.biortech.2008.01.069 
15. Jasicka-Misiak, I., Makowicz, E., Stanek, N.: Chromatographic fingerprint, antioxidant activity, and colour characteristic of polish goldenrod (Solidago virgaurea L.) honey and flower. Eur. Food Res. Technol. 244, 1169-1184 (2018). https://doi.org/10.1007/ s00217-018-3034-3

16. Izydorczyk, G., Skrzypczak, D., Kocek, D., Mironiuk, M., Witek-Krowiak, A., Moustakas, K., Chojnacka, K.: Valorization of bio-based post-extraction residues of goldenrod and alfalfa as energy pellets. Energy (2020). https://doi.org/10.1016/j.energy. 2020.116898

17. Sahin, K., Onderci, M., Sahin, N., Aydin, S.: Effects of dietary chromium picolinate and ascorbic acid supplementation on egg production, egg quality and some serum metabolites of laying hens reared under a low ambient temperature $\left(6^{\circ} \mathrm{C}\right)$. Arch. Anim. Nutr. 56, 41-49 (2002). https://doi.org/10.1080/00039 420214174

18. Sahin, N., Hayirli, A., Orhan, C., Tuzcu, M., Komorowski, J.R., Sahin, K.: Effects of the supplemental chromium form on performance and metabolic profile in laying hens exposed to heat stress. Poult. Sci. 97, 1298-1305 (2018). https://doi.org/10.3382/ ps/pex435

19. Onderci, M., Sahin, N., Sahin, K., Kilic, N.: Antioxidant properties of chromium and zinc: in vivo effects on digestibility, lipid peroxidation, antioxidant vitamins, and some minerals under a low ambient temperature. Biol. Trace Elem. Res. 92, 139-150 (2003). https://doi.org/10.1385/BTER:92:2:139

20. Zhang, Y.N., Zhang, H.J., Wang, J., Yue, H.Y., Qi, X.L., Wu, S.G., Qi, G.H.: Effect of dietary supplementation of organic or inorganic zinc on carbonic anhydrase activity in eggshell formation and quality of aged laying hens. Poult. Sci. 96, 2176-2183 (2017). https://doi.org/10.3382/ps/pew490

21. Tiecher, T.L., Ceretta, C.A., Ferreira, P.A.A., Lourenzi, C.R., Tiecher, T., Girotto, E., Nicoloso, F.T., Soriani, H.H., De Conti, L., Mimmo, T., Cesco, S., Brunetto, G.: The potential of Zea mays L. in remediating copper and zinc contaminated soils for grapevine production. Geoderma 262, 52-61 (2016). https://doi.org/10. 1016/j.geoderma.2015.08.015

22. Ibiang, Y.B., Mitsumoto, H., Sakamoto, K.: Bradyrhizobia and arbuscular mycorrhizal fungi modulate manganese, iron, phosphorus, and polyphenols in soybean (Glycine max (L.) Merr.) under excess zinc. Environ. Exp. Bot. 137, 1-13 (2017). https://doi.org/ 10.1016/j.envexpbot.2017.01.011

23. Shahid, M., Shamshad, S., Rafiq, M., Khalid, S., Bibi, I., Niazi, N.K., Dumat, C., Rashid, M.I.: Chromium speciation, bioavailability, uptake, toxicity and detoxification in soil-plant system: a review. Chemosphere 178, 513-533 (2017). https://doi.org/10. 1016/j.chemosphere.2017.03.074

24. Drelinkiewicz, A., Knapik, A., Waksmundzka-Góra, A., Bukowska, A., Bukowski, W., Noworól, J.: Functional gel-type resin based palladium catalysts: the role of polymer properties in the hydrogenation of the $\mathrm{C}$ \{double bond, long $\} \mathrm{C}$ bond of maleic and fumaric acids, the isomers of dicarboxylic acids. React. Funct. Polym. 68, 1059-1071 (2008). https://doi.org/10.1016/j.reactfunct polym.2008.02.008

25. Armbruster, M.H., Austin, J.B.: The adsorption of gases on plane surfaces of mica. J. Am. Chem. Soc. 60, 467-475 (1918). https:// doi.org/10.1021/ja01269a066

26. Freundlich, H.: Uber die adsorption in Losungen. ZeitschriftPhysik LXII, 385-471 (1957)

27. Malhotra, M., Suresh, S., Garg, A.: Tea waste derived activated carbon for the adsorption of sodium diclofenac from wastewater: adsorbent characteristics, adsorption isotherms, kinetics, and thermodynamics. Environ. Sci. Pollut. Res. 25, 32210-32220 (2018). https://doi.org/10.1007/s11356-018-3148-y

28. Jeppu, G.P., Clement, T.P.: A modified Langmuir-Freundlich isotherm model for simulating $\mathrm{pH}$-dependent adsorption effects.
J. Contam. Hydrol. 129-130, 46-53 (2012). https://doi.org/10. 1016/j.jconhyd.2011.12.001

29. Upton, G.J.G.: Fisher's exact test. R. Stat. Soc. 155, 395-402 (1992)

30. ISTA: International rules for seed testing: edition 2016 (2016)

31. Jyske, T., Hölttä, T.: Comparison of phloem and xylem hydraulic architecture in Picea abies stems. New Phytol. 205, 102-115 (2015). https://doi.org/10.1111/nph.12973

32. Thomson, C.A., Chesney, D.J.: Supercritical carbon dioxide extraction of 2, 4-dichlorophenol from food crop tissues. Anal. Chem. 64, 848-853 (1992). https://doi.org/10.1021/ac00032a006

33. Ziyath, A.M., Mahbub, P., Goonetilleke, A., Adebajo, M.O., Kokot, S., Oloyede, A.: Influence of physical and chemical parameters on the treatment of heavy metals in polluted stormwater using zeolite: a review. J. Water Resour. Prot. 03, 758-767 (2011). https://doi.org/10.4236/jwarp.2011.310086

34. Vanholme, R., Demedts, B., Morreel, K., Ralph, J., Boerjan, W.: Lignin biosynthesis and structure. Plant Physiol. 153, 895-905 (2010). https://doi.org/10.1104/pp.110.155119

35. Yruela, I.: Copper in plants. Braz. J. Plant Physiol. 17, 145-156 (2005). https://doi.org/10.1590/s1677-04202005000100012

36. Faried, A., Zareh, M., Nafady, N., Mohamed, M.: Green synthesis of silver nanoparticles from capitula extract of some Launaea (Asteraceae) with notes on their taxonomic significance. Egypt. J. Bot. (2018). https://doi.org/10.21608/ejbo.2018.1375.1111

37. Nasef, S., ElNesr, E., Hafez, F., Badawy, N., Slim, S.: Gamma irradiation induced preparation of gum arabic/ poly (vinyl alcohol) copolymer hydrogels for removal of heavy metal ions from wastewater. Arab. J. Nucl. Sci. Appl. (2019). https://doi.org/10. 21608/ajnsa.2019.15587.1246

38. Yah, W.O., Takahara, A., Lvov, Y.M.: Selective modification of halloysite lumen with octadecylphosphonic acid: new inorganic tubular micelle. J. Am. Chem. Soc. 134, 1853-1859 (2012). https://doi.org/10.1021/ja210258y

39. Hoekman, S.K., Broch, A., Robbins, C.: Hydrothermal carbonization (HTC) of lignocellulosic biomass. Energy Fuels 25, 18021810 (2011). https://doi.org/10.1021/ef101745n

40. Hussain, N., Abbasi, T., Abbasi, S.A.: Vermicomposting transforms allelopathic parthenium into a benign organic fertilizer. J. Environ. Manag. 180, 180-189 (2016). https://doi.org/10.1016/j. jenvman.2016.05.013

41. Adel, A.M., Abd El-Wahab, Z.H., Ibrahim, A.A., Al-Shemy, M.T.: Characterization of microcrystalline cellulose prepared from lignocellulosic materials. Part II: physicochemical properties. Carbohydr. Polym. 83, 676-687 (2011). https://doi.org/10.1016/j.carbp ol.2010.08.039

42. Islam, N.U., Jalil, K., Shahid, M., Rauf, A., Muhammad, N., Khan, A., Shah, M.R., Khan, M.A.: Green synthesis and biological activities of gold nanoparticles functionalized with Salix alba. Arab. J. Chem. 12, 2914-2925 (2019). https://doi.org/10.1016/j.arabjc. 2015.06.025

43. Pérez Marín, A.B., Aguilar, M.I., Meseguer, V.F., Ortuño, J.F., Sáez, J., Lloréns, M.: Biosorption of chromium (III) by orange (Citrus cinensis) waste: batch and continuous studies. Chem. Eng. J. 155, 199-206 (2009). https://doi.org/10.1016/j.cej.2009.07.034

44. Li, M., Wang, L.J., Li, D., Cheng, Y.L., Adhikari, B.: Preparation and characterization of cellulose nanofibers from de-pectinated sugar beet pulp. Carbohydr. Polym. 102, 136-143 (2014). https:// doi.org/10.1016/j.carbpol.2013.11.021

45. Hu, Z.H., Omer, A.M., Ouyang, X.K., Yu, D.: Fabrication of carboxylated cellulose nanocrystal/sodium alginate hydrogel beads for adsorption of $\mathrm{Pb}$ (II) from aqueous solution. Int. J. Biol. Macromol. 108, 149-157 (2018). https://doi.org/10.1016/j.ijbiomac. 2017.11.171

46. Kazemi, M., Khodaiyan, F., Labbafi, M., Saeid Hosseini, S., Hojjati, M.: Pistachio green hull pectin: optimization of 
microwave-assisted extraction and evaluation of its physicochemical, structural and functional properties. Food Chem. 271, 663-672 (2019). https://doi.org/10.1016/j.foodchem.2018.07.212

47. Reynel-Avila, H.E., Mendoza-Castillo, D.I., Olumide, A.A., Bonilla-Petriciolet, A.: A survey of multi-component sorption models for the competitive removal of heavy metal ions using bush mango and flamboyant biomasses. J. Mol. Liq. 224, 10411054 (2016). https://doi.org/10.1016/j.molliq.2016.10.061

48. De Ruiter, J.: Carboxylic Acid Structure and Chemistry : Part 2. Springer, New York (2005)

49. Repo, E., Petrus, R., Sillanpää, M., Warchoł, J.K.: Equilibrium studies on the adsorption of $\mathrm{Co}(\mathrm{II})$ and $\mathrm{Ni}(\mathrm{II})$ by modified silica gels: one-component and binary systems. Chem. Eng. J. 172, 376-385 (2011). https://doi.org/10.1016/j.cej.2011.06.019

50. Ma, W., Gu, Y., Lu, J., Yuan, L., Zhao, R.: Effects of chromium propionate on egg production, egg quality, plasma biochemical parameters, and egg chromium deposition in late-phase laying hens. Biol. Trace Elem. Res. 157, 113-119 (2014). https://doi. org/10.1007/s12011-013-9875-5

51. Króliczewska, B., Zawadzki, W., Skiba, T., Miâta, D.: Effects of chromium supplementation on chicken broiler growth and carcass. Acta Vet. Brno 74, 543-549 (2005)

52. EU Commission: List of authorised additives in feedingstuffs; published in application of Article 9t of Council Directive 70/524/ EEC concerning additives in feedingstuffs. Off. J. Eur. Union C50, $1-144$ (2004)

53. Tuhy, L., Samoraj, M., Chojnacka, K.: Evaluation of nutrients bioavailability from fertilizers in in vivo tests. Interdiscip. J. Eng. Sci. 1, 10-13 (2013)

54. Sharififar, A., Nazari, M., Asghari, H.R.: Effect of ultrasonic waves on seed germination of Atriplex lentiformis, Cuminum cyminum, and Zygophyllum eurypterum. J. Appl. Res. Med.
Aromat. Plants. 2, 102-104 (2015). https://doi.org/10.1016/j.jarmap.2015.05.003

55. Deng, B., Tian, S., Li, S., Guo, M., Liu, H., Li, Y., Wang, Q., Zhao, X.: A simple, rapid and efficient method for essential element supplementation based on seed germination. Food Chem. 325, 126827 (2020). https://doi.org/10.1016/j.foodchem.2020. 126827

56. Samreen, T., Shah, H.U., Ullah, S., Javid, M.: Zinc effect on growth rate, chlorophyll, protein and mineral contents of hydroponically grown mungbeans plant (Vigna radiata). Arab. J. Chem. 10, S1802-S1807 (2017). https://doi.org/10.1016/j.arabjc.2013. 07.005

57. Adamo, P., Iavazzo, P., Albanese, S., Agrelli, D., De Vivo, B., Lima, A.: Bioavailability and soil-to-plant transfer factors as indicators of potentially toxic element contamination in agricultural soils. Sci. Total Environ. 500-501, 11-22 (2014). https://doi.org/ 10.1016/j.scitotenv.2014.08.085

58. Izydorczyk, G., Sienkiewicz-Cholewa, U., Baśladyńska, S., Kocek, D., Mironiuk, M., Chojnacka, K.: New environmentally friendly bio-based micronutrient fertilizer by biosorption: from laboratory studies to the field. Sci. Total Environ. 710, 136061 (2020). https://doi.org/10.1016/j.scitotenv.2019.136061

59. Dean, J.R.: Bioavailability, Bioaccessibility and Mobility of Environmental Contaminants, p. 32. Wiley, Hoboken (2007)

60. Zou, T., Xu, N., Hu, G., Pang, J., Xu, H.: Biofortification of soybean sprouts with zinc and bioaccessibility of zinc in the sprouts. J. Sci. Food Agric. 94, 3053-3060 (2014). https://doi.org/10.1002/ jsfa. 6658

Publisher's Note Springer Nature remains neutral with regard to jurisdictional claims in published maps and institutional affiliations. 